\title{
Spatial changes in zooplankton communities in a strong human-mediated river ecosystem
}

\author{
Robert Czerniawski ${ }^{1}{ }^{\text {， Monika Kowalska-Góralska }}{ }^{\text {Corresp. } 2}$ \\ ${ }^{1}$ Department of General Zoology/Centre of Molecular Biology and Biotechnology, University of Szczecin, Szczecin, Poland \\ 2 Institute of Biology/Department of Hydrobiology and Aquaculture, Wrocław University of Environmental and Life Sciences, Wroclaw, Poland \\ Corresponding Author: Monika Kowalska-Góralska \\ Email address: monika.kowalska-goralska@upwr.edu.pl
}

River damming causes a decrease in water current velocity which leads to an increase in richness and abundance of organisms atypical for running waters. Zooplankton is a representative example of such organisms. The influx of zooplankton from carp ponds is an additional factor that increases richness and abundance of zooplankton in rivers. We hypothesized that zooplankton dispersing form the carp ponds colonize the impoundments in river and the richness of zooplankton increase in impoundments by development of new species, not observed in the upstream. The zooplankton was collected monthly from April to September of 2013 and 2014 . Sampling sites were located in the Barycz river (in the lotic sections and in the dam impoundments), as well as in its tributaries, which are the outlets of carp ponds. The most changes in zooplankton richness and abundance were observed at sites located within the dam impoundments, especially in relation to the lower values of the current velocity. Since the abundance of pelagic rotifers, cladocerans and copepods in the carp pond outlets was similar to that at lower sites in the Barycz, the influence of the carp pond outlets on the abundance in the dam and lotic sections was significant. The river itself in its impounded sections provides advantageous conditions for retention and colonization by a high abundance of zooplankton dispersing from the carp ponds, and for the development of species not occurred in the upstream, which, in turn, increases richness. 
1 Spatial changes in zooplankton communities in a strong human-mediated river ecosystem 2

3 Robert Czerniawski ${ }^{1}$, , Monika Kowalska-Góralska*

$4{ }^{1}$ Department of General Zoology/Centre of Molecular Biology and Biotechnology, University of 5 Szczecin, Szczecin, Poland

62 Institute of Biology/Department of Hydrobiology and Aquaculture, Wrocław University of

7 Environmental and Life Sciences, Wrocław, Poland

$8 *$ Corresponding Author

9 E-mail: monika.kowalska-goralska@upwr.edu.pl

\section{Abstract}

River damming causes a decrease in water current velocity which leads to an increase in richness and abundance of organisms atypical for running waters. Zooplankton is a representative example of such organisms. The influx of zooplankton from carp ponds is an additional factor that increases richness and abundance of zooplankton in rivers. We hypothesized that zooplankton dispersing form the carp ponds colonize the impoundments in river and the richness of zooplankton increase in impoundments by development of new species, not observed in the upstream. The zooplankton was collected monthly from April to September of 2013 and 2014. Sampling sites were located in the Barycz river (in the lotic sections and in the dam impoundments), as well as in its tributaries, which are the outlets of carp ponds. The most changes in zooplankton richness and abundance were observed at sites located within the dam impoundments, especially in relation to the lower values of the current velocity. Since the abundance of pelagic rotifers, cladocerans and copepods in the carp pond outlets was similar to that at lower sites in the Barycz, the influence of the carp pond outlets on the abundance in the dam and lotic sections was significant. The river itself in its impounded sections provides advantageous conditions for retention and colonization by a high abundance of zooplankton dispersing from the carp ponds, and for the development of species not occurred in the upstream, which, in turn, increases richness.

\section{Data Availability Statement}


31 All data supporting this study are provided as supplementary information accompanying this 32 paper.

33

\section{Introduction}

Catchment management is one of the factors that determines the functioning of a region and comprises numerous technical measures that depend on a region's needs, river-bed maintenance, agricultural drainage, water impoundments for fish farming or securing energy needs, flood control systems, and water retention (Jones et al. 2004; Soranno et al. 2015; Ullah et al. 2018). On the other hand, there are also works, such as restoration of river stretches, which intend to make the area more appealing, increase its economic and biodiversity potential, as well as the environmental value (Dufour \& Piégay 2009; Zawal et al. 2016). Consequently, all the technical measures, which alter the river-bed and the hydrological conditions, affect the biological functioning of the lotic sections.

Human-made dams are one of the most important technical measures that break the river continuum. Oftentimes, they cause irreversible alterations in rivers, and distort their natural flow (Allan \& Castillo 2007). Such alterations are reflected in physicochemical and biological variables, as well as the loss and replacement of typical lotic species by typical stagnant water species. A large number of studies examine how large dams in large rivers cause changes in environmental conditions, whereas few papers address the impact of small dams in small rivers or streams. However, small dams impounding a water of up to $4 \mathrm{~m}$ cause similar changes in river ecosystems, albeit on a much smaller scale. In small rivers, even small dams can affect the flora and fauna composition, by inducing rapid changes in hydrological and physicochemical variables (Cumming 2004; Wu et al. 2010; Zhou et al. 2008). Small dams create distinct physical and ecological conditions that are relatively different from the ones found in free-flowing lotic sections. This is manifested by a reduction of current velocity, increase of water retention time and increase of nutrient content.

These new conditions e.g. long water retention time and low current velocity are suitable for the growth of zooplankton populations, that in turn are a good indicator of hydrological changes (Czerniawski \& Domagala 2014; Ot'ahel'ová \& Valachovič 2002; Zhou et al. 2008). Zooplankton can develop in stagnant waters or in slow-flowing waters with current velocities lower than $0.1 \mathrm{~m} \mathrm{~s}^{-1}$ (Czerniawski \& Domagala 2014; Zhou et al. 2008). Given that, zooplankton 
62 reacts rapidly to the hydrological changes caused by dams. Until now, the influence of dams on 63 zooplankton communities has been studied primarily in large rivers, with dammed water up to more than 15 m (Akopian et al. 1999; Doi et al. 2008; Pourriot et al. 1997; Żurek \& Dumnicka 1989). However, only a few studies have investigated the influence of small dams on zooplankton communities (Czerniawski \& Domagala 2014; Zhou et al. 2008). Small dams promote the formation of biotopes of the ecotone type, in which the zooplankton community develops features similar to or different from those communities in lakes and large reservoirs (Czerniawski \& Domagala 2014; Zhou et al. 2008).

Another process leading to alterations in a man-changed environment is catchment transformation, i.e. creation of retention reservoirs or fish ponds joined with main channel of the river. The amount of dead and live organic matter (including zooplankton) significantly increases in such reservoirs (Kloskowski 2011; Meijer et al. 1990; Rahman et al. 2008). An example of artificial reservoirs are carp ponds, which lead to the increase in organic matter, and cause an influx of the organic matter to the rivers. High biomass of common carp cause an increase of nutrients, turbidity and suspended solids, hence, these basins have a strong influence on water quality and aquatic community structure (Nieoczym \& Kloskowski 2014; Parkos et al. 2003). The dispersion of carp-pond plankters can enrich the river with high densities or new zooplankton species. The inorganic and organic nutrients in the water column can drift to the outlet section thereafter, and then be dispersed into rivers.

None of the abovementioned studies investigated the concurrent impact of zooplankton influx from carp ponds and small dams impounding water of these carp ponds on the zooplankton communities in rivers. Moreover, in the case of the present study, small river dams can create suitable conditions for the dispersed carp-pond plankters, and for the development of new zooplankton species (not present in the upstream). That is why the sum of alterations occurring in a small river and its immediate surroundings can enhance changes in qualitative and quantitative structure of zooplankton in a different manner than dams alone. This phenomenon has not been examined. Therefore, we decided to investigate the concurrent impact of both factors on zooplankton communities in a small river: i) impact of the dams impounding the river water, and ii) impact of the zooplankton influx from the carp ponds outlets.

Construction of a small dam and the zooplankton influx from the carp pond outlets would significantly shape the zooplankton community in a river environment. The overall goal of the 
93

94

95

96

97

98

99

100

101

102

103

104

105

106

107

108

109

110

111

112

113

114

115

116

117

118

119

120

121

122

123

study was to examine the distribution of the zooplankton richness and abundance in a river dammed in many places and connected with the carp ponds. The following tasks were proposed: a comparison of the zooplankton communities between the free-flowing lotic sections and the impounded sections of the river (1), and a comparison of the zooplankton communities between the carp pond outlets and the river (2). We hypothesized that zooplankton dispersing form the carp ponds can colonize the impoundments in river (1) and the richness of zooplankton increase in impoundments by development of new species, not observed in the upstream (2).

\section{Methods}

\section{Study area}

This study was performed in the Barycz and its few tributaries which are outlets of carp ponds (drainage of the Oder river, SW Poland) (Fig. 1). The Barycz is a river in the Lower Silesian Province in southwestern Poland. It is a right tributary of the Oder river. The Barycz is $139 \mathrm{~km}$ long, has a catchment area of $5526 \mathrm{~km}^{2}$, and is characterized by a mean slope of $0.035 \%$. The catchment of the Barycz Valley Landscape Park is an important wetland reserve. Carp ponds in the Barycz Valley are the largest carp breeding ponds in Central Europe. They constitute the biggest complex of fish ponds and the oldest group of artificial reservoirs in Poland; they were built as early as the 15th and 16th century for carp farming (Gąbka et al. 2007). The location of the ponds in the Barycz Valley allows the inflow of gravitational water. The Barycz provides water for the carp ponds, therefore numerous dams and impoundments are located along the river. Currently, the total area of fish ponds in the catchment of the Barycz covers approximately 7500 ha. The proportion of the agricultural area of the Barycz in the catchment is approximately $80 \%$. From August to October, an accelerated discharge of water from the carp ponds into the Barycz is observed. In the examined stretch of the Barycz 31 dams with a hydraulic height of 1.2 $\mathrm{m}$ to $4.6 \mathrm{~m}$ are located.

Sampling sites were located in the Barycz, in the lotic, free-flowing sections (R 1. R 2, R 3, R 4), at the dam impoundments (D 1, D 2, D 3, D 4, D 5), and in the tributaries of the Barycz, which are also carp pond outlets (T 1, T 2, T 3, T 4, T 5) (Fig. 1). The hydraulic heights of the dams at D 1, D 2, D 3, D 4 and D 5 were respectively, $2.5 \mathrm{~m}, 2.5 \mathrm{~m}, 1.6 \mathrm{~m}, 2.3 \mathrm{~m}$ and $1.6 \mathrm{~m}$. In Barycz river Lagrangian scheme according to which cross-sections were sampled in a downstream sequence with the sampling interval approximating the time of travel between sites. The 
124 sampling sites of Barycz were chosen under account 1) influence of the carp pond outlets, 3)

125 influence of the dam impoundments on zooplankton communities in downstream, 3) easy access.

126 Sand was the dominant component in the sediments of the lotic sections of the Barycz.

127 Whereas, the sediments of the impoundments were marshy (contained leaf litter), with many

128 small floodplains and slackwater areas. The riparian zone of the impoundments was densely 129 covered by emerging macrophytes (dominants: Glyceria maxima, Phragmintes communis,

130 Sparganiun erectum), whereas the central zone of the bed impoundment was covered by elodeids

131 (dominants: Potamogeton natans, Ceratophyllum demersum, Potamogeton perfoliatus,

132 Sagittaria sagittifolia). The riparian zone of the lotic sections was sporadically covered by 133 emerging macrophytes (dominants: Glyceria maxima, Sparganiun erectum), whereas its central 134 bed was sporadically covered by Potamogeton perfoliatus and Sagittaria sagittifolia.

135 Tributaries - outflows of the carp ponds - were regulated channels with a sandy bottom.

136 The owners of carp ponds remove regularly a aquatic vegetation from both the riparian zone and 137 the central part of the bed to ensure free and unobstructed water flow to the Barycz. Tributaries 138 between the carp ponds and the Barycz did not include any slack-water areas or floodplains. 139 Therefore, the morphological conditions of the outlets were characterized by a relatively fast 140 water current (from $0.36 \mathrm{~m} \mathrm{~s}^{-1}$ to $0.48 \mathrm{~m} \mathrm{~s}^{-1}$ ). No particular field sampling permits with regard to 141 the site locations, e.g. the national park or other protected area and protected species, were 142 needed.

\section{Sampling methods}

144 The zooplankton was collected monthly from April to September of 2013 and $2014(n=12)$. At each site, $50 \mathrm{~L}$ of water was collected from the river current. The samples were collected using a Van Dorn 5-liter water sampler (KC Denmark) at 5 depths: 20\%, 40\%,60\%, 80\%, and at the surface (Czerniawski \& Domagała 2014). At each depth level, 10 L of water was collected to obtain $50 \mathrm{~L}$ of water. The water was filtered through a plankton net with a mesh of $30 \mu \mathrm{m}$. The samples were then concentrated to $150 \mathrm{ml}$ and fixed in a $4-5 \%$ formalin solution. The contents of the samples were counted in a Sedgewick-Rafter counting chamber in ten 3-ml sub-samples. A Nikon Eclipse 50i microscope was used for identification. Species were identified using the

152 keys described by Nogrady (Nogrady et al. 1993) and Rybak \& Błędzki (Rybak \& Błędzki 153 2010). 
Measurements of chlorophyll $a$ content were made in situ using the Hydrolab DS 5

155

156

157

158

159

160

161

162

163

164

165

166

167

168

169

170

171

172

173

174

175

176

177

178

179

180

181

182

183

184 multiparameter probe (USA). At each site, water velocity, width and depth were measured with an electromagnetic water flow sensor OTT (Germany) to determine water discharge. A crosssection of the stream channel was divided into five vertical subsections. In each subsection, the area was obtained by measuring the width and depth of the subsection, and water velocity was determined using a current meter. Water discharge in each subsection was calculated by multiplying the subsection area by the measured velocity. The total discharge was then counted by summing up the discharge values of each subsection.

\section{Data analyses}

Rotifers were divided into two categories, according to habitat preference-pelagic species (plankton) and benthic, epiphytic, epilithic species associated with the substratum otherwise known as benthic species (Radwan 2004; Zhou et al. 2008). Taxonomical similarity between the sites was calculated using the Sorensen's index. We used the Kruskal-Wallis test $(\mathrm{P}<0.05)$ for checking the significance of differences in the chlorophyll $a$ content, discharge and current velocity values, and the richness (number of species) and the abundance of each zooplankton group among the sites. Post-hoc multiple comparisons of mean ranks for all groups were conducted $(\mathrm{P}<0.05)$ to determine the significant differences in the zooplankton richness and abundance between the sites. Cluster analysis based on Euclidean distance was used to identify groups of similar sites of tributaries, impoundments and lotic sections with regard to the richness and the abundance of zooplankton. To illustrate the similarities between the sites (lotic sections R1 -R4 vs. dammed sections D1 -D5 vs. tributaries T1 -T5) in terms of all taxa abundance, nonmetric multidimensional scaling ordination (nMDS) technique was used. The grouping in the nMDS ordination was based on the Bray-Curtis distances (Oksanen et al. 2016). In order to determine the influence of environmental factors on richness and the abundance of zooplankton, Spearman's correlation was applied $(\mathrm{P}<0.05)$. For the evaluation of the correlation between environmental factors versus the zooplankton richness and abundance in the Barycz, the following factors were considered: ND—number of dams above the site in the Barycz, DCPdistance between the site in the Barycz and the closest carp pond in the pond system, NCOnumber of the carp pond outlets above the site in the Barycz, TPelRotR — richness of pelagic rotifers in the closest tributary above a site in the Barycz, TBenRotR-richness of benthic rotifers in the closest tributary above a site in the Barycz, TClaR-richness of cladocerans in the 
185 closest tributary above a site in the Barycz, TCopR_richness of copepods in the closest tributary 186 above a site in the Barycz, TPelRotA-abundance of pelagic rotifers in the closest tributary 187 above the site in the Barycz, TBenRotA - abundance of benthic rotifers in the closest tributary 188 above the site in the Barycz, TClaA-abundance of cladocerans in the closest tributary above 189 the site in the Barycz, TNaupCA - abundance of copepods Nauplii in the closest tributary above 190 the site in the Barycz, TCopA-abundance of copepods in the closest tributary above the site in 191 the Barycz.

192 The environmental conditions at the tributary sites were very similar and had absolutely 193 no effect on the development of the zooplankton composition. The zooplankton composition in 194 the tributaries (carp pond outlets) depended entirely on the conditions present in the carp pond 195 upstream. Hence, when calculating the correlation between zooplankton and environmental 196 factors, the environmental conditions at the outlets were not taken into consideration, as they 197 could alter the end results.

\section{Results}

200

201

202

203

204

205

206

207

208

209

210

211

212

213

214

215

\section{Environmental factors}

The means of the measured abiotic variables of chlorophyll $a$ content, discharge, current velocity and values of constant factors are shown in Table 1. Generally, a spatial increase of the chlorophyll $a$ values was observed. However, in the lotic sections, the chlorophyll $a$ content decreased in relation with the dam sites. Significantly lower current velocity values were observed at the dam sites than at the lotic section. From R 2, a significant increase in discharge occurred, and another rapid increase in discharge was observed from D 5.

\section{Taxonomic composition}

A spatial increase in the number of zooplankton taxa was observed (Table 2). A higher number of taxa was noted at the dam sites in the Barycz than in its tributaries (carp pond outlets) (Table 2). Only at R 1 - the first site of the Barycz (not influenced by the tributaries and the dams) - the number of taxa was the lowest.

All taxa observed in tributaries were also detected in the Barycz (Table 2). However, not all species observed in the Barycz, especially the ones at dam sites, occurred in samples collected at the tributaries. Among them were rotifers: Scaridium longicauda, Synchaeta oblonga, 
216 Testudinella. patina, Trichocerca. capucina, Trichocerca similis; cladocerans: Eurycercus 217 glacialis, Bosmina. gibbera, Ceriodaphnia laticaudata, Disparolona rostrata, Graptoleberis 218 testudinaria, Pleuroxus. trigonellus, Simocephalus lusaticus; copepods: Mesocyclops gigas. The 219 frequency (number of samples in which a species occurred in relation to number of all samples expressed as a percentage) of different taxa was higher at the Barycz sites than in the tributaries e.g. Brachionus sp, Cephalodella apocolea, Euchlanis dilatata, Mytilina sp., Alona sp., Eucyslops macruroides, Eudiaptopus gracilis (Table 2).

223

\section{Sorensen's similarity}

The Sorensen taxonomic similarity index value between the tributaries and the sites below them in the Barycz was more than $60 \%$ (Figure 2). The farther the distance from the tributary to the Barycz sites, the lower the Sorensen similarity index value. Taxonomic similarity between the subsequent sites of the Barycz was relatively high (more than $60 \%$ ). The highest similarity (more than 90\%) was observed between the last sites in the Barycz-D 5 and R 4 .

\section{Richness of zooplankton}

In the case of pelagic rotifers, the higher the mean richness in the tributaries, the higher values of this parameter were observed at the subsequent sites below a tributary in the Barycz (Figure 3). However, no significant differences in richness of pelagic rotifers occurred between these sites $(\mathrm{P}>0.05)$. The mean richness of pelagic rotifers in $\mathrm{R} 1$ was significantly lower than in each tributary $(\mathrm{P}<0.05)$, apart from $\mathrm{T} 1(\mathrm{P}>0.05)$ (Table 3). The mean richness of benthic rotifers was similar at each site and did not differ significantly between the sites in the tributaries, dams and lotic sections of the Barycz $(\mathrm{P}>0.05)$ (Table 3$)$.

In the case of cladocerans, mean richness differed significantly from most sites in the Barycz and its tributaries only at $\mathrm{R} 1(\mathrm{P}<0.05)$ (Table 3$)$, where the mean richness was lower than compared with the other sites. The mean richness of copepods differed significantly only between R 1 and T 2. Contrary to pelagic rotifers, crustaceans (cladocerans and copepods) were characterized by a slightly higher mean richness at the dam sites than in the tributaries $(\mathrm{P}>0.05)$. In the lotic sections of the Barycz, no significant decrease in the richness in relation with the impoundments was observed. Therefore, the mean richness of crustaceans was similar between the Barycz (the dam and the lotic section sites) and its tributaries. 
The richness similarity dendrogram of cluster analysis shows that the tributary sites are

248

249

250

251

252

253

254

255

256

257

258

259

260

261

262

263

264

265

266

267

268

269

270

271

272

273

274

275

276

277 rather separated from other sites with respect to pelagic rotifers, cladocerans and copepods (Figure 4). The richness of these groups at the first lotic section sites is farther from the last sites in the impoundments. The dendrogram does not show such differences in the richness of benthic rotifers.

\section{Abundance of zooplankton}

Pelagic rotifers contributed to the increase in zooplankton abundance in the Barycz below the tributaries or dams (Figure 5). However, no significant differences in the abundance of pelagic rotifers occurred between these sites $(\mathrm{P}>0.05)$ (Table 4). The mean abundance of pelagic rotifers at R 1 was significantly lower than at the tributary sites $(\mathrm{P}<0.05)$.

The mean abundance of benthic rotifers did not differ significantly between the sites $(\mathrm{P}>0.05)$ (Table 4). Generally, with respect to the subsequent sites, a higher abundance of benthic rotifers occurred in the Barycz (dam and lotic sections) than in the tributaries (Figure 5).

Similarly to pelagic rotifers, cladocerans and copepods (Nauplii and the remaining stages). demonstrated a increase in the mean abundance in the Barycz below the tributaries (Figure 5). However, contrary to the richness values, the abundance of crustaceans in the dam sites was lower than in the tributaries, and higher than in the lotic sections. The abundance of cladocerans at R 1 was significantly lower than at the tributary sites and D $2(\mathrm{P}<0.05)$ (Table 4). Copepods (all stages) obtained the lowest abundance at R 1. The abundance of Nauplii at R 1 was significantly lower than at T 2, T 3 and T 5 . While the abundance of other copepods stages at $\mathrm{R} 1$ was significantly lower than at the sites of the tributaries $(\mathrm{P}<0.05)$. Considering the subsequent sites below the tributaries, there were no significant differences in the abundance of crustacean groups between the sites $(\mathrm{P}>0.05)$.

Based on the abundance of pelagic rotifers, cladocerans, copepods (Nauplii and the remaining stages), the cluster analysis shows a spatial similarity between the tributaries and the Barycz sites (Figure 6). Such similarity is not observed when it comes to the abundance of benthic rotifers.

The nMDS ordination showed a high similarity between the tributary sites. The dam sites exhibit less similarity and the lotic section sites showed the smallest similarity (Figure 7). The nMDS ordination also indicated the greatest similarity in the zooplankton abundance occurred 
278 between the tributary sites and the dammed sites, and not between the tributary sites and the lotic

279 section sites. The analysis showed also a similarity between subsequent sites (generally the 280 distances between subsequent sites of tributary, dam and lotic section were the smallest).

At all sites, crustaceans were abundance dominants (Figure 8). Between the tributaries

282

283

284

285

286

287

288

289

290

291

292

293

294

295

296

297

298

299

300

301

302

303

304

305

306

307

308

and the sites at the dam or lotic sections located below, a similar percentage of the same groups comprised of the total zooplankton abundance (Figure 8). At the lotic section sites (in relation with the dam upstream), a decrease in the percentage of abundance of cladocerans and copepods was observed. The same species were abundance dominants at the carp pond outlets (tributaries) and below their mouths in the Barycz (in the impoundments and lotic sections). This pattern was best manifested by Bosmina longirostris, Chydorus sphaericus, Nauplii Cyclopoida and Acanthocyclops robustus (Table 3).

\section{Impact of environmental variables}

At the Barycz sites, richness of each group positively correlated with the chlorophyll $a$ content $(\mathrm{P}<0.05)$ (Table 5). Pelagic rotifers and cladocerans richness also positively correlated with the values of ND and $\mathrm{NCO}(\mathrm{P}<0.05)$. Moreover, a negative correlation between the richness of copepods vs. the current velocity and the DCP was observed $(\mathrm{P}<0.05)$. In the Barycz, richness of each group revealed a positive correlation with the richness of the same group in the closest tributary (carp pond outlet) $(\mathrm{P}<0.05)$.

The abundance in the Barycz, a pattern of Spearman's significant correlation coefficients similar to that of richness was observed (Table 6). Each group correlated positively with the chlorophyll $a$ content and negatively with the current velocity $(\mathrm{P}<0.05)$. Abundance of copepods correlated negatively with the DCP values $(\mathrm{P}<0.05)$. Abundance of each group correlated positively with the abundance of the same group in the closest tributary (carp pond outlet) $(\mathrm{P}<0.05)$.

\section{Discussion}

Task 1. A comparison of the zooplankton communities between the free-flowing sections and impounded sections of the Barycz.

Spatial pattern of zooplankton richness and abundance in the Barycz shows that the value of the zooplankton parameters increases with the distance from the river source. River 
309 Continuum Concept (Vanotte et al. 1980) defines this as a phenomenon typically occurring in 310 large rivers. However, in case of the Barycz continuum, it was the dam impoundments that 311 affected the zooplankton communities as was seen by the increase in species numbers right after 312 the dams. Generally, this phenomenon is discussed in the context of large rivers with large dams 313 that create large reservoirs. In such large reservoirs richness and abundance of zooplankton is 314 similar to that of lakes (Akopian et al. 1999; Doi et al. 2008; Pourriot et al. 1997; Żurek \& 315 Dumnicka 1989). In regard with the present study results we could state that also small dams 316 cause significant growth in zooplankton richness and abundance between the upstream and the 317 downstream. A similar pattern of zooplankton community distribution in a small river 318 impounded by human-made dams or beaver dams was observed by (Czerniawski 2013; 319 Czerniawski \& Domagala 2014; Zhou et al. 2008). We observed that in the impoundments of the 320 Barycz, the zooplankton richness and abundance were high, and comparable to or even higher 321 than those in typical temperate limnetic basins, e.g. eutrophic lakes or reservoirs (Gołdyn \& 322 Kowalczewska-Madura 2008; Karabin et al. 1997; Lair 2006).

323 The main variables that contribute to increase the richness and abundance of zooplankton 324 in the Barycz are: the decrease of the current velocity, longer water retention time or greater areas of open-water zones, a higher number of slackwater areas, floodplains and adjacent water bodies (Richardson 1992; Zhou et al. 2008; Nielsen et al. 2013; Czerniawski \& Domagala 2014). The majority of microfauna, including freshwater zooplankton, is unable to persist if the current velocity is higher than $0.1 \mathrm{~m} \mathrm{~s}^{-1}$ (Lair 2006; Richardson 1992). Such low current velocity values noted at the dam sites in the Barycz were favorable for the occurrence of zooplankton and for the increase of their populations.

The phenomenon that many species were observed in the Barycz but not in the pond outlets indicates that the dams provided advantageous conditions for the development of new species (not observed in upstream and in the carp pond outlets). This refers especially to small cladocerans (Alonidae) and littoral rotifers (Euchlanis sp., Mytilina sp.) occurring in an environment associated with macrophytes (Rybak \& Błędzki 2010). The more rapid increase in the richness of the abovementioned taxa, and the maintained high density of zooplankton in the impoundments was possible because features typical of stagnant water basins covered by macrophytes appeared in the impoundments (Czerniawski 2013; Czerniawski \& Domagala 2014; 
340 appearance of new species of pelagic, epiphytic and epilithic, rotifers and crustaceans, and, in 341 turn, the growth of the zooplankton abundance (Czerniawski 2013; Czerniawski et al. 2013; 342 Nielsen et al. 2013; Richardson 1992). Grabowska et al. (Grabowska et al. 2013) and 343 Czerniawski and Pilecka-Rapacz (Czerniawski \& Pilecka-Rapacz 2011; Grabowska et al. 2013) 344 also observed a percentage domination in the abundance of small cladocerans in a shallow 345 riverine section covered by macrophytes. Richardson (Richardson 1992) and De Bie et al. (De 346 Bie et al. 2008) found that the predominance of small cladocerans in running waters may be due 347 to the fact that these species live in close association with the substratum or exhibit a strong 348 habitat selection in favor of well-structured littoral zones, which may reduce their vulnerability 349 to downstream washout. The bed covered with macrophytes is the key factor that positively 350 affects the richness of zooplankton (Kornijow et al. 2005; Kuczynska-Kippen \& Nagengast 351 2006). In the impoundments of the Barycz, numerous slackwater areas were observed, from 352 which zooplankton could be washed into the main channel (Czerniawski 2013; Nielsen et al. 353 2010; Richardson 1992). Very good trophic conditions for filter-feeding plankters could have 354 occurred in the Barycz dam impoundments because of the high concentration of chlorophyll $a$. 355 Richness and abundance of each zooplankton group were significantly and positively correlated 356 with the chlorophyll $a$ values, which were also higher in the impoundments than in the lotic 357 section. These effects can be due to the associated improved nutritional conditions for filter358 feeding plankters. Such a correlation is more frequently observed in stagnant waters (Gołdyn \& Kowalczewska-Madura 2008; Kamarainen et al. 2008; Levesque et al. 2010) and slow-flowing waters (Czerniawski 2012; Czerniawski et al. 2016). Despite low densities of Euchlanis sp., Mytilina sp. and Alonidae, they were good indicators of the changes in the zooplankton

362

363

364

365

366

367

368

369 communities in the dammed Barycz river. So, not only macroinvertebrates or ichthyofauna react on the anthropogenic changes in river bed. Perhaps Water Framework Directive (WFD) should take into account also the zooplankton to biological evaluation of rivers. However few years ago zooplankton was proposed as a good bioindicator of the lakes conditions. Zooplankton may play a pivotal role in the trophic network of stagnant basins ecosystems, but it has not been included in the WFD guidelines as part of biological evaluation, despite that many authors have shown strong indicative properties of zooplankton (Jeppesen et al. 2011; Ejsmont-Karabin, 2012; Ejsmont-Karabin \& Karabin, 2013). 
It is generally known that zooplankton disperse passively in aquatic ecosystems and they

371 can colonize new habitats (Havel \& Shurin 2004). Also zooplankton transfer from lakes and 372 reservoirs into the river is well documented (e.g. Basu \& Pick 1997; Pourriot et al. 1997;

373 Czerniawski \& Domagała 2014). Drifting zooplankton can colonize the river if its bed offer

374 zones with low current velocity or with stagnant water e.g. slackwaters, impoundments, 375 floodplains (Czerniawski \& Sługocki 2017; Czerniawski \& Sługocki 2018). The Barycz is a kind 376 of impoundment-cascade system in which richness and abundance of zooplankton increase with 377 the number of dams. The drift from the upstream impoundments would influence richness and 378 abundance in the upstream and the dam sites. That is because what is present in a dam site, 379 would first have to drift through an upstream site to get to a dam site. The dam sites provide a 380 place for drifting zooplankton to proliferate, and increase in abundance, and as a result rare 381 species (e.g. Euchlanis sp., Mytilina sp.), pelagic rotifers, and small cladocerans are more easily 382 detected when sampling. Richness and abundance of pelagic rotifers and cladocerans correlated 383 positively with the number of dams in river. Thus, passive zooplankton dispersion into the 384 impoundments could be affected by the impoundments upstream, and mainly Rotifera, that 385 demonstrate the best ability to colonize new habitats by short life span, reproduce through 386 cyclical parthenogenesis, production the resting eggs that are easily transferred (Ejsmont387 Karabin \& Kruk 1998, Wallace 2002).

388 The zooplankton abundance was reduced along the section stretching from the dam sites 389 to the lotic sections downstream. The decreased richness and density of zooplankton at the 390 downstream sites typically occurs in the outlet sections of lakes or reservoirs and it depend on 391 level of turbulence, values of discharge and current velocities. Higher values of these variables 392 can have negative effect on fish predation on zooplankton, grazing by suspension-feeding, filter393 feeding or net-spinning of macrozoobenthos, or settling to sediments (Chang et al. 2008; 394 Czerniawski et al. 2013; Nielsen et al. 2013; Thorp \& Casper 2003). In Barycz relatively low 395 values of current velocity were observed. However, with the distance from the last dam, the 396 zooplankton abundance and chlorophyll $a$ concentration was rapidly reduced, so the impact of 397 dam sites and carp ponds outlets on the zooplankton in lower section of Barycz and on their 398 recipient - Oder, is rather small. 
400

401

402

403

404

405

406

407

408

409

410

411

412

413

414

415

416

417

418

419

420

421

422

423

424

425

426

427

428

429

430

\section{Task 2. A comparison of the zooplankton communities between the carp pond outlets and the} river.

It is certain that because of the dam presence, richness and abundance of zooplankton in the Barycz were high, and they were higher than in the lotic sections of other rivers, and even in the reservoirs of other larger rivers (Akopian et al. 1999; Doi et al. 2008; Pourriot et al. 1997). This pattern was affected by an additional factor, namely a connection between the river and the carp pond outlets which could have allowed the zooplankton to drift passively. We observed a similarity in zooplankton abundance between the carp pond outlets and the subsequent sites in the Barycz. This indicates that there is a influence of the carp pond outlets on the zooplankton abundance in the Barycz. While the differences between the carp pond outlets and the impoundments in the Barycz were particularly apparent when it comes to richness and species similarity.

It is surprising that crustaceans were the abundance dominants at all sites of the Barycz. The zooplankton in rivers, as well as small and large reservoirs, mainly consist of Cyclopoida nauplii and minor species of rotifers (Akopian et al. 1999; Czerniawski \& Domagala 2014; Doi et al. 2008; Pourriot et al. 1997; Zhou et al. 2008). In the present study, we have observed a different pattern, which was found in a non-typical river system. It was a carp pond outletimpoundment-river system in which the composition of dominants depended on the sites that provided the best conditions for colonization and development. In this case, these were primarily carp ponds whose outlets carried zooplankton mass into the Barycz. The impoundments in which zooplankton from the tributaries remained and could maintain its abundance at a stable level played only a minor role. Dominants in the pond outlets that were carried into the Barycz were small cladocerans (bosminids and chydorids), that once passively drifted into the Barycz and dominated in the river as well. Bosminids and chydorids are small species that abundantly colonize both the pelagial and the littoral of either shallow and deep reservoirs, in which they can be dominant (Gasiorowski \& Szeroczynska 2004; Rybak \& Błędzki 2010; Soto \& De los Rios 2006).

Cottenie et al. (2003) claimed that connected water basins have similar zooplankton structures if they are environmentally similar. Results of our study show that the spatial pattern of zooplankton communities in the Barycz river confirms this statement. The number of taxa at environmentally similar sites (i.e. at different dam sites, different lotic sites and different 
431 tributary sites) was similar, although the species similarity between these sites was not high.

432 Taxonomic similarity achieved high values between the subsequent sites, e.g. a tributary vs. an

433 impoundment, or lotic section sites and dam sites vs. lotic section sites. Hence, the number of 434 species was comparable at similar sites, however, these species were replaced by other species.

435 This fact demonstrates the high influence of the tributaries and the dam sites on the development 436 of zooplankton species structure in downstream locations.

437 To fully address the problem of carp pond influence on zooplankton population in the

438 Barycz we would have to examine the zooplankton in the ponds and its similarity to the Barycz.

439 However, it was not the objective of this study. We can be certain, that the influx of zooplankton

440 in the carp pond outlets would provide enough data to determine the influence of carp ponds on

441 zooplankton and the Barycz. That is because plankters found in ponds dispersed passively to the

442 outlets, which was proved by the similarities found between zooplankton communities in water

443 basins and their outlet sections.

445 Conclusion

446 Spatial changes in the zooplankton composition in the Barycz river reflected the effects

447 of physical changes induced by the dam impoundments and by dispersion of zooplankton from 448 the carp ponds outlets. In the case of pelagic rotifers, the higher the mean richness and 449 abundance in the tributaries, the higher values of this parameters were observed at the 450 subsequent sites below a tributary in the Barycz.. Since the abundance of most groups (except 451 for benthic rotifers) in the tributaries was similar to that at lower sites in the Barycz, the 452 influence of the tributaries on the abundance in the dam and lotic sections is significant. 453 Similarly significant was the influence of the impoundments on the zooplankton abundance in 454 the lotic sections. The carp ponds outlets cause a large influx of zooplankton biomass to the 455 river. Moreover, the river itself in its impounded sections provides advantageous conditions for 456 retention and colonization by a high abundance of zooplankton dispersing from the carp ponds, 457 and for the development of new species (not observed in the upstream), which, in turn, increases 458 richness. This pattern was the most noticeable in the case of the crustaceans (cladocerans and 459 copepods) which were characterized by a higher mean richness at the dam sites than in the 460 tributaries. The Barycz is kind of an impoundment-cascade system, in which richness and 461 abundance of zooplankton increase with the number of dams. However, richness and abundance 
462 decrease in case of the last site, despite the fact, that there is a number of dams below it and no 463 pond influence. This shows that there is a clear influence of carp pond outlets, which are the

464

465

466

467

468

469

470

471

472

473

474

475

476

477

478

479

480

481

482

483

484

485

486

487

488

489

490

491

492

493

494

495

496

497

498

499

500

501 source of zooplankton in the Barycz.

The presented study demonstrated how significant the effect of alterations to the river bed, as well as alterations to the water reservoirs in its catchment area (influx of the zooplankton from carp ponds) is to the biological changes in the river. The influx of live organic matter from the carp ponds and the dams has an impact on the zooplankton communities in the river downstream. The influx of zooplankton from carp ponds undoubtedly affected the increase in the zooplankton abundance in the river, while the dams had an effect on retaining this abundance and increasing richness.

.

\section{References}

Akopian M, Garnier J, and Pourriot R. 1999. A large reservoir as a source of zooplankton for the river: structure of the populations and influence of fish predation. Journal of Plankton Research 21:285-297. 10.1093/plankt/21.2.285

Allan JD, and Castillo MM. 2007. Stream ecology: structure and function of running waters: Springer Science \& Business Media.

Chang KH, Doi H, Imai H, Gunji F, and Nakano S. 2008. Longitudinal changes in zooplankton distribution below a reservoir outfall with reference to river planktivory. Limnology 9:125-133. 10.1007/s10201-008-0244-6

Cumming GS. 2004. The impact of low-head dams on fish species richness in Wisconsin, USA. Ecological Applications 14:1495-1506. 10.1890/03-5306

Czerniawski R. 2012. SPATIAL PATTERN OF POTAMOZOOPLANKTON COMMUNITY OF THE SLOWLY FLOWING FISHLESS STREAM IN RELATION TO ABIOTIC AND BIOTIC FACTORS. Polish Journal of Ecology 60:323-338.

Czerniawski R. 2013. Zooplankton community changes between forest and meadow sections in small headwater streams, NW Poland. Biologia 68:448-458. 10.2478/s11756-013-0170-x

Czerniawski R, and Domagala J. 2014. Small dams profoundly alter the spatial and temporal composition of zooplankton communities in running waters. International Review of Hydrobiology 99:300311. 10.1002/iroh.201301674

Czerniawski R, and Pilecka-Rapacz M. 2011. Summer zooplankton in small rivers in relation to selected conditions. Central European Journal of Biology 6:659-674. 10.2478/s11535-011-0024-x

Czerniawski R, Pilecka-Rapacz M, and Domagala J. 2013. Zooplankton communities of inter-connected sections of lower River Oder (NW Poland). Central European Journal of Biology 8:18-29. 10.2478/s11535-012-0110-8

Czerniawski R, Slugocki L, and Kowalska-Goralska M. 2016. Diurnal Changes of Zooplankton Community Reduction Rate at Lake Outlets and Related Environmental Factors. Plos One 11. 10.1371/journal.pone.0158837 
502

503

504

505

506

507

508

509

510

511

512

513

514

515

516

517

518

519

520

521

522

523

524

525

526

527

528

529

530

531

532

533

534

535

536

537

538

539

540

541

542

543

544

545

546

547

De Bie T, Declerck S, Martens K, De Meester L, and Brendonck L. 2008. A comparative analysis of cladoceran communities from different water body types: patterns in community composition and diversity. Hydrobiologia 597:19-27. 10.1007/s10750-007-9222-y

Doi $\mathrm{H}$, Chang $\mathrm{KH}$, Ando T, Imai H, Nakano SI, Kajimoto A, and Katano I. 2008. Drifting plankton from a reservoir subsidize downstream food webs and alter community structure. Oecologia 156:363371. 10.1007/s00442-008-0988-z

Dufour S, and Piégay H. 2009. From the myth of a lost paradise to targeted river restoration: forget natural references and focus on human benefits. River research and applications 25:568-581.

Gasiorowski M, and Szeroczynska K. 2004. Abrupt changes in Bosmina (Cladocera, Crustacea) assemblages during the history of the Ostrowite Lake (northern Poland). Hydrobiologia 526:137144. 10.1023/B:HYDR.0000041592.09564.e6

Gołdyn R, and Kowalczewska-Madura K. 2008. Interactions between phytoplankton and zooplankton in the hypertrophic Swarzędzkie Lake in western Poland. Journal of Plankton Research 30:33-42. 10.1093/plankt/fbm086

Grabowska M, Ejsmont-Karabin J, and Karpowicz M. 2013. RESERVOIR-RIVER RELATIONSHIPS IN LOWLAND, SHALLOW, EUTROPHIC SYSTEMS: AN IMPACT OF ZOOPLANKTON FROM HYPERTROPHIC RESERVOIR ON RIVER ZOOPLANKTON. Polish Journal of Ecology 61:759-768.

Havel J, and Shurin J. 2004. Mechanisms, effects and scales od dispersal in freshwater zooplankton. Limnology and Oceanography 49: 1229-1238.

Jones J, Knowlton M, Obrecht D, and Cook E. 2004. Importance of landscape variables and morphology on nutrients in Missouri reservoirs. Canadian Journal of Fisheries and Aquatic Sciences 61:15031512.

Kamarainen AM, Rowland FE, Biggs R, and Carpenter SR. 2008. Zooplankton and the total phosphorus chlorophyll a relationship: hierarchical Bayesian analysis of measurement error. Canadian Journal of Fisheries and Aquatic Sciences 65:2644-2655. 10.1139/f08-161

Karabin A, EjsmontKarabin J, and Kornatowska R. 1997. Eutrophication processes in a shallow, macrophyte-dominated lake - Factors influencing zooplankton structure and density in Lake Luknajno (Poland). Hydrobiologia 342:401-409. 10.1023/a:1017003810282

Kloskowski J. 2011. Impact of common carp Cyprinus carpio on aquatic communities: direct trophic effects versus habitat deterioration. Fundamental and Applied Limnology 178:245-255. 10.1127/1863-9135/2011/0178-0245

Kornijow R, Vakkilainen K, Horppila J, Luokkanen E, and Kairesalo T. 2005. Impacts of a submerged plant (Elodea canadensis) on interactions between roach (Rutilus rutilus) and its invertebrate prey communities in a lake littoral zone. Freshwater Biology 50:262-276. 10.1111/j.13652427.2004.01318.x

Kuczynska-Kippen NM, and Nagengast B. 2006. The influence of the spatial structure of hydromacrophytes and differentiating habitat on the structure of rotifer and cladoceran communities. Hydrobiologia 559:203-212. 10.1007/s10750-005-0867-0

Lair N. 2006. A review of regulation mechanisms of metazoan plankton in riverine ecosystems: Aquatic habitat versus biota. River Research and Applications 22:567-593. 10.1002/rra.923

Levesque S, Beisner BE, and Peres-Neto PR. 2010. Meso-scale distributions of lake zooplankton reveal spatially and temporally varying trophic cascades. Journal of Plankton Research 32:1369-1384. 10.1093/plankt/fbq064

Meijer ML, Lammens E, Raat AJP, Grimm MP, and Hosper SH. 1990. IMPACT OF CYPRINIDS ON ZOOPLANKTON AND ALGAE IN 10 DRAINABLE PONDS. Hydrobiologia 191:275-284. $10.1007 /$ bf00026063 
Nielsen DL, Gigney H, and Watson G. 2010. Riverine habitat heterogeneity: the role of slackwaters in providing hydrologic buffers for benthic microfauna. Hydrobiologia 638:181-191. 10.1007/s10750-009-0039-8

Nielsen DL, Podnar K, Watts RJ, and Wilson AL. 2013. Empirical evidence linking increased hydrologic stability with decreased biotic diversity within wetlands. Hydrobiologia 708:81-96. 10.1007/s10750-011-0989-5

Nieoczym M, and Kloskowski J. 2014. The role of body size in the impact of common carp Cyprinus carpio o(n) water quality, zooplankton, and macrobenthos in ponds. International Review of Hydrobiology 99:212-221. 10.1002/iroh.201301644

Nogrady T, Wallace RL, and Snell TW. 1993. Guides to the Identification of the Microinvertebrates of the Continental Waters of the World. Hague: SPB Academic Publishers.

Ot'ahel'ová H, and Valachovič M. 2002. Effects of the Gabčíkovo hydroelectric-station on aquatic vegetation of the Danube river (Slovakia). Preslia 74:323-331.

Parkos JJ, Santucci VJ, and Wahl DH. 2003. Effects of adult common carp (Cyprinus carpio)on multiple trophic levels in shallow mesocosms. Canadian Journal of Fisheries and Aquatic Sciences 60:182192. 10.1139/f03-011

Pourriot R, Rougier C, and Miquelis A. 1997. Origin and development of river zooplankton: Example of the Marne. p 143-148.

Radwan S. 2004. Rotifers. . Łódź: Uniwersytet Łódzki.

Rahman MM, Verdegem M, Nagelkerke L, Wahab MA, Milstein A, and Verreth J. 2008. Effects of common carp Cyprinus carpio (L.) and feed addition in rohu Labeo rohita (Hamilton) ponds on nutrient partitioning among fish, plankton and benthos. Aquaculture Research 39:85-95. 10.1111/j.1365-2109.2007.01877.x

Richardson WB. 1992. MICROCRUSTACEA IN FLOWING WATER - EXPERIMENTAL-ANALYSIS OF WASHOUT TIMES AND A FIELD-TEST. Freshwater Biology 28:217-230. 10.1111/j.1365-2427.1992.tb00578.x

Rybak JI, and Błędzki LA. 2010. Planktonic Crustaceans of Freshwaters. . Warszawa: Uniwersytet Warszawski.

Soranno PA, Cheruvelil KS, Wagner T, Webster KE, and Bremigan MT. 2015. Effects of land use on lake nutrients: the importance of scale, hydrologic connectivity, and region. PloS one 10:e0135454.

Soto D, and De los Rios P. 2006. Influence of trophic status and conductivity on zooplankton composition in lakes and ponds of Torres del Paine National Park (Chile). Biologia 61:541-546. 10.2478/s11756-006-0088-7

Thorp JH, and Casper AF. 2003. Importance of biotic interactions in large rivers: An experiment with planktivorous fish, dreissenid mussels and zooplankton in the St Lawrence River. River Research and Applications 19:265-279. 10.1002/rra.703

Ullah KA, Jiang J, and Wang P. 2018. Land use impacts on surface water quality by statistical approaches. Global Journal of Environmental Science and Management 4:231-250.

Wu N, Tang T, Fu X, Jiang W, Li F, Zhou S, Cai Q, and Fohrer N. 2010. Impacts of cascade run-of-river dams on benthic diatoms in the Xiangxi River, China. Aquatic Sciences 72:117-125. 10.1007/s00027-009-0121-3

Zawal A, Sulikowska-Drozd A, Stępień E, Jankowiak $Ł$, and Szlauer-Łukaszewska A. 2016. Regeneration of the molluscan fauna of a small lowland river after dredging. Fundamental and Applied Limnology/Archiv für Hydrobiologie 187:281-293.

Zhou SC, Tang T, Wu NC, Fu XC, and Cai QH. 2008. Impacts of a small dam on riverine zooplankton. International Review of Hydrobiology 93:297-311. 10.1002/iroh.200711038

Żurek R, and Dumnicka E. 1989. The rate of population in a river after leasing a dam reservoir. Arch Hydrobiol Ergebn Limnol 33:549-561. 
596

597

598

599

600

601

602

603

604

605

606

607

608

609

610

611

612

613

614 
Figure 1

Study area

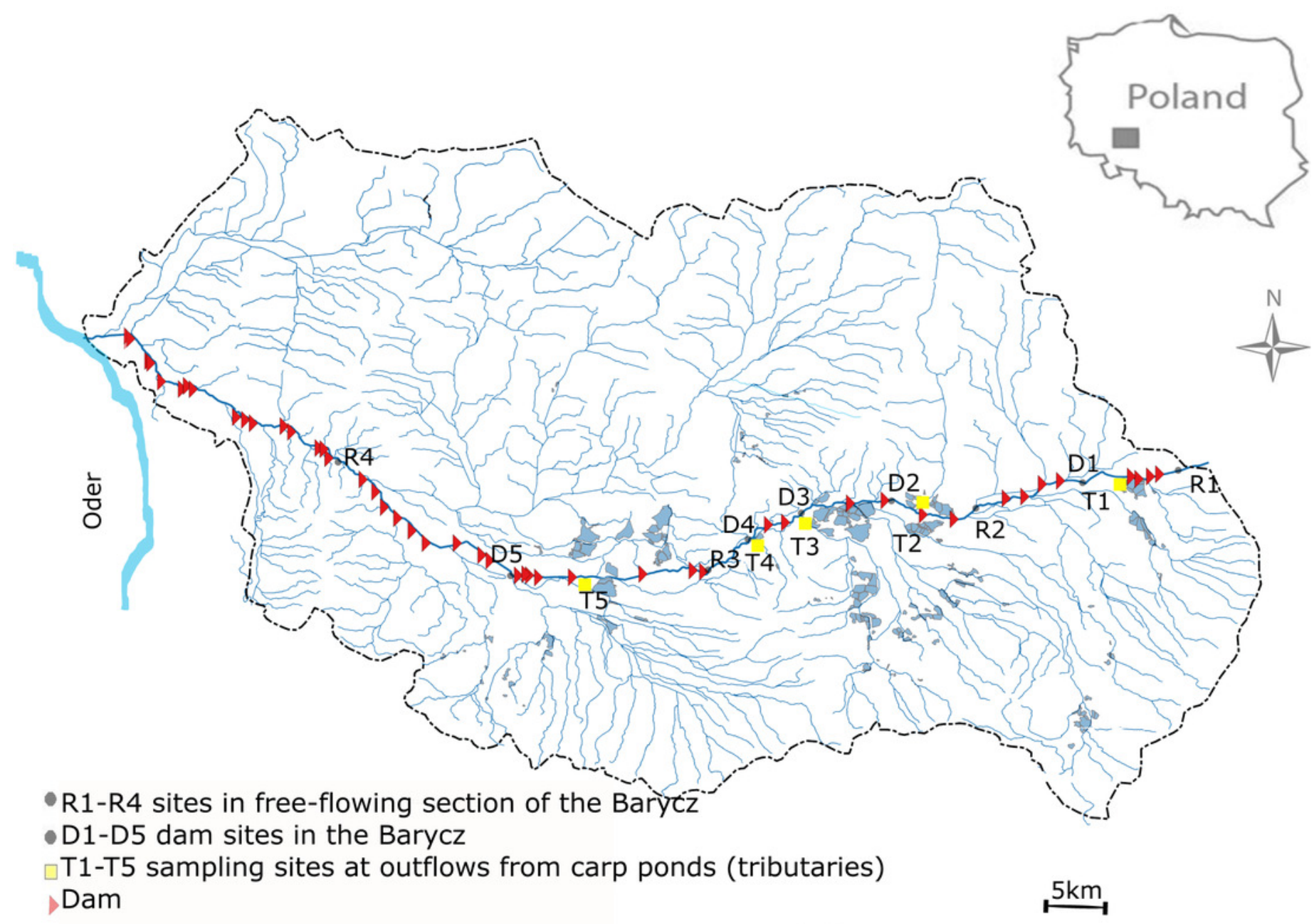


Figure 2

Sorensen's similarity index value between the free-flowing (lotic) sites of the Barycz river (R), the dam sites of the Barycz (D) and the tributaries of the Barycz (T).

\section{UPGMA}

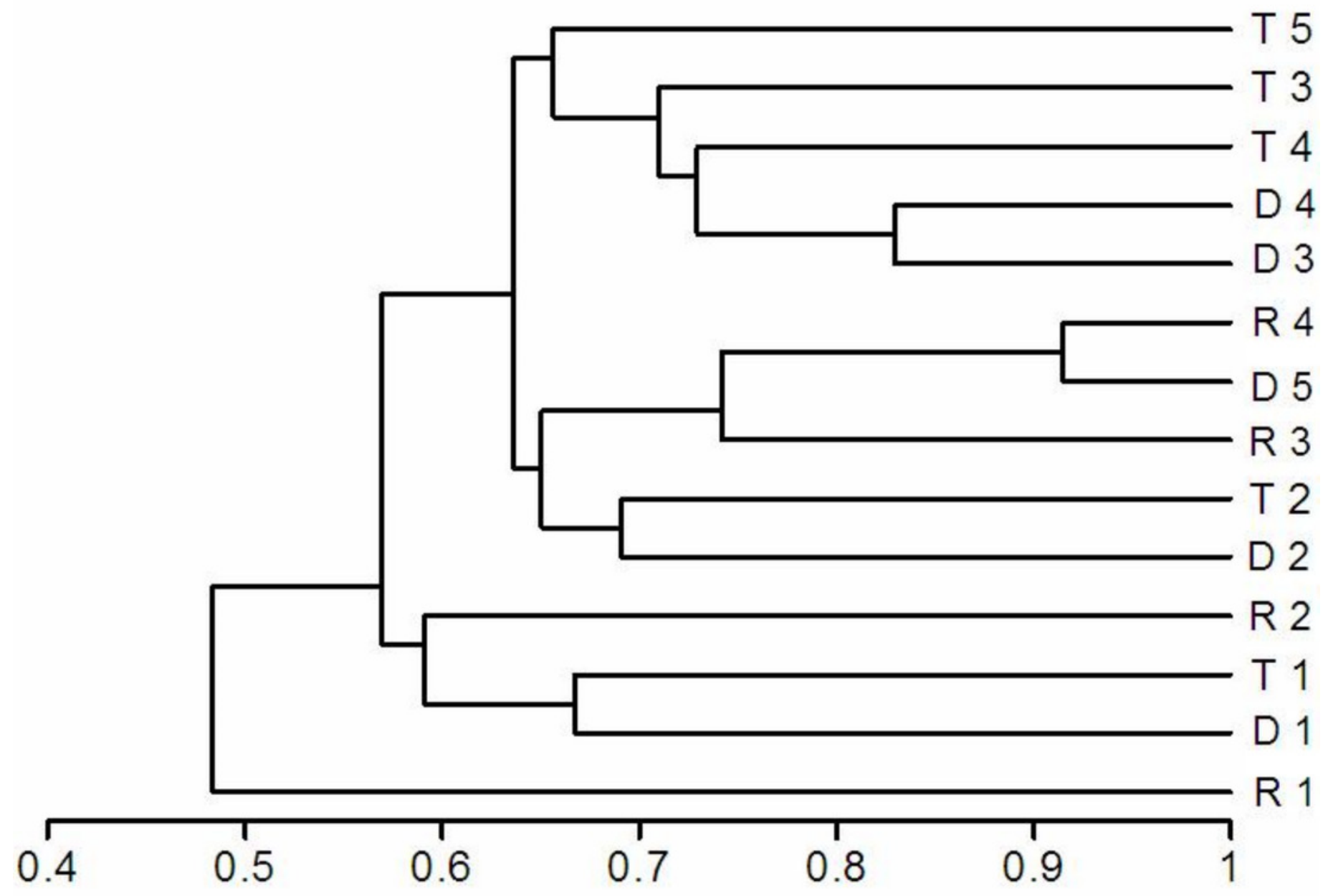




\section{Figure 3}

Spatial distribution of the zooplankton richness in the Barycz river.

R 1-4: sites in the free-flowing waters of the Barycz, D 1-5: sites in the dams of Barycz, T 1-5: sites in the tributaries of the Barycz. 


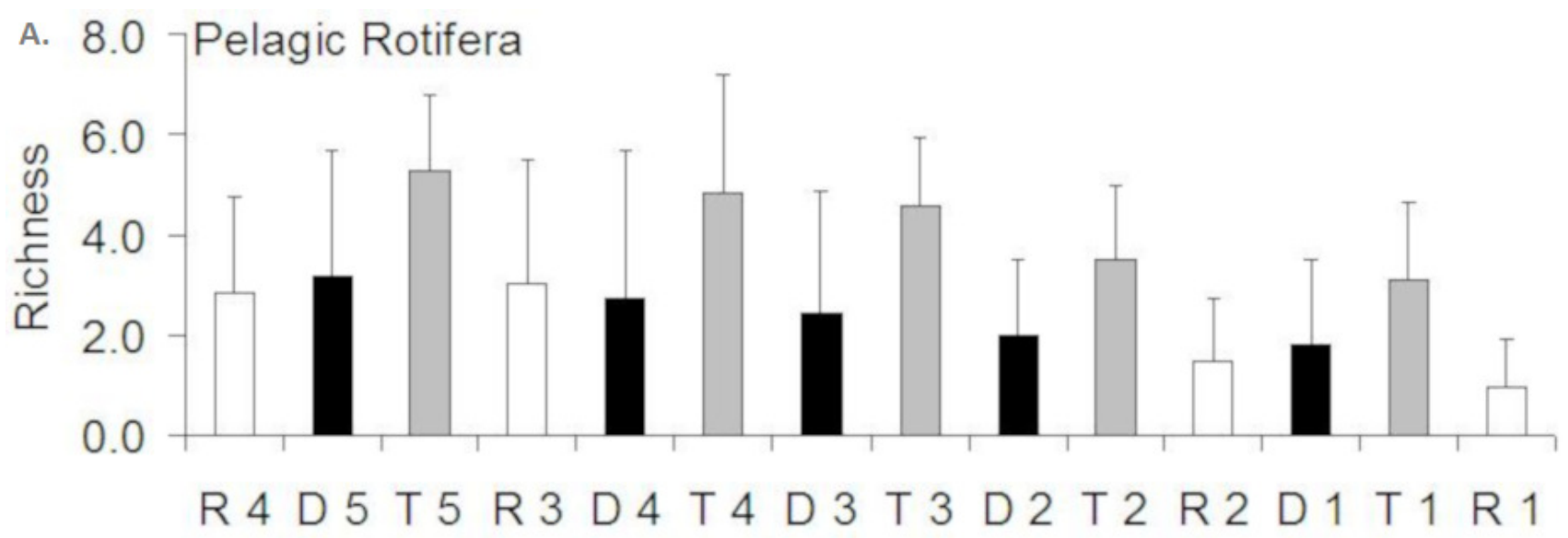

B. 4.07 Benthic Rotifera

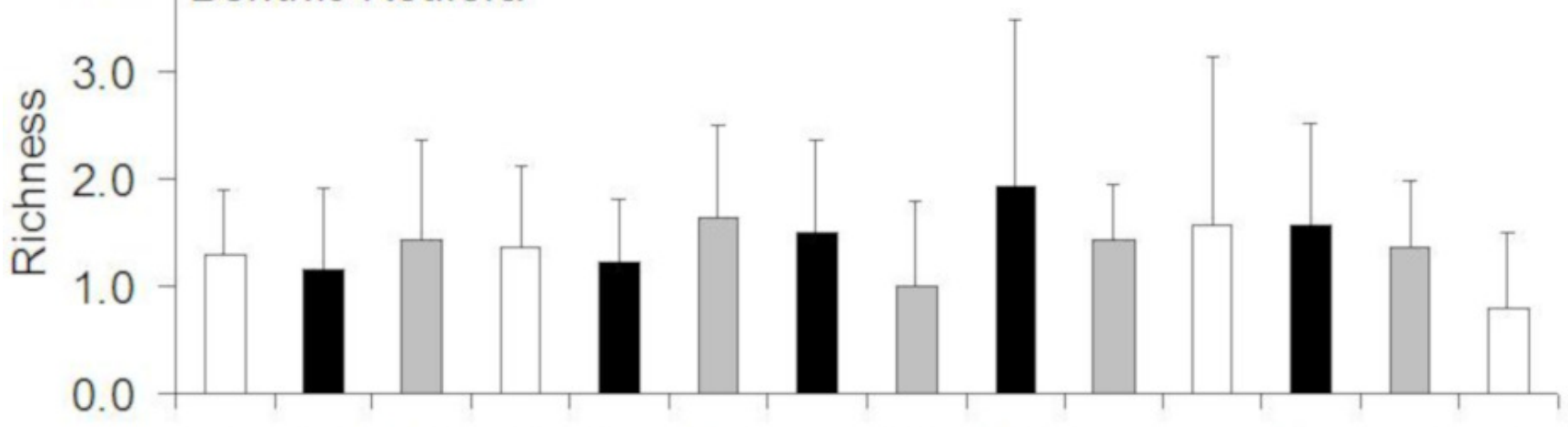

R 4 D 5 T 5 R 3 D 4 T 4 D 3 T 3 D 2 T 2 R 2 D 1 T 1 R 1

c. 12.0 Cladocera

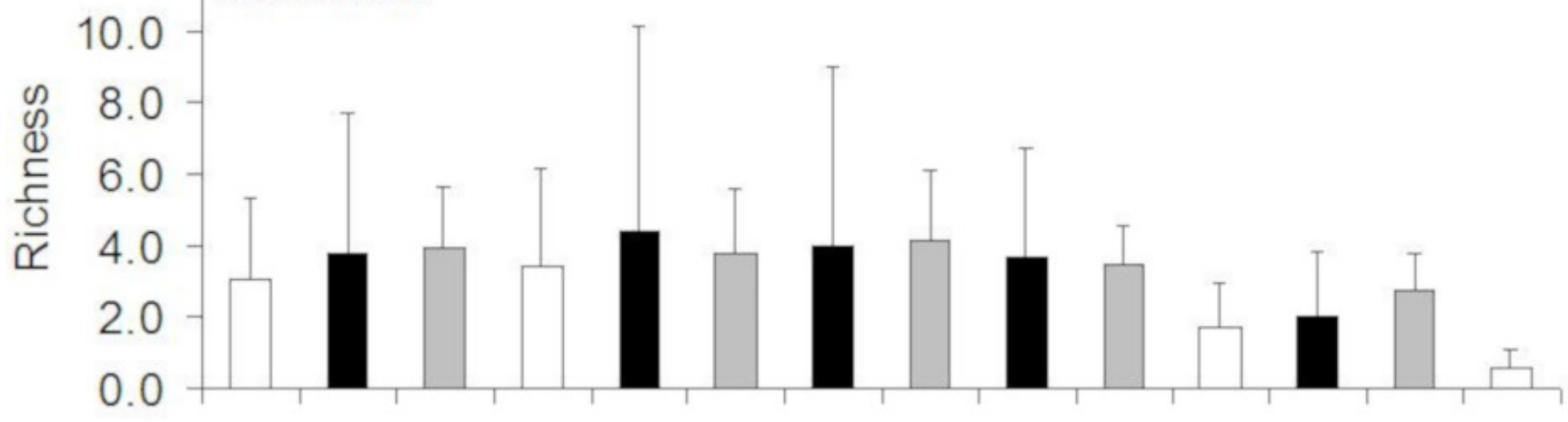

R 4 D 5 T 5 R 3 D 44 D 3 T 3 D 2 T 2 R 2 D 1 T 1 R 1

D. 2.5$\urcorner$ Copepoda

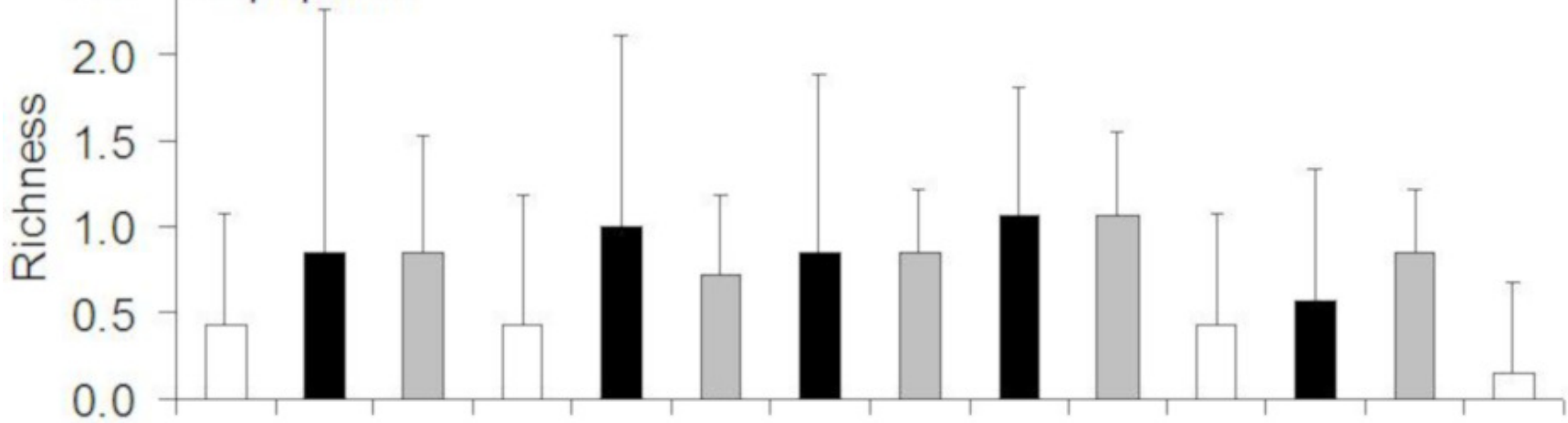

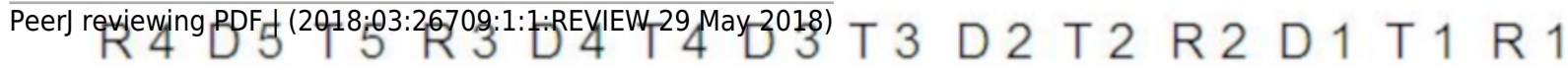


Figure 4

Dendrogram (cluster analysis) of the sites in the Barycz river.

R 1-4: sites in the free-flowing waters of the Barycz river, D 1-5: sites in the dams of the Barycz river, T 1-5: sites in the tributaries of the Barycz river based on the richness of pelagic rotifers, benthic rotifers, cladocerans and copepods.
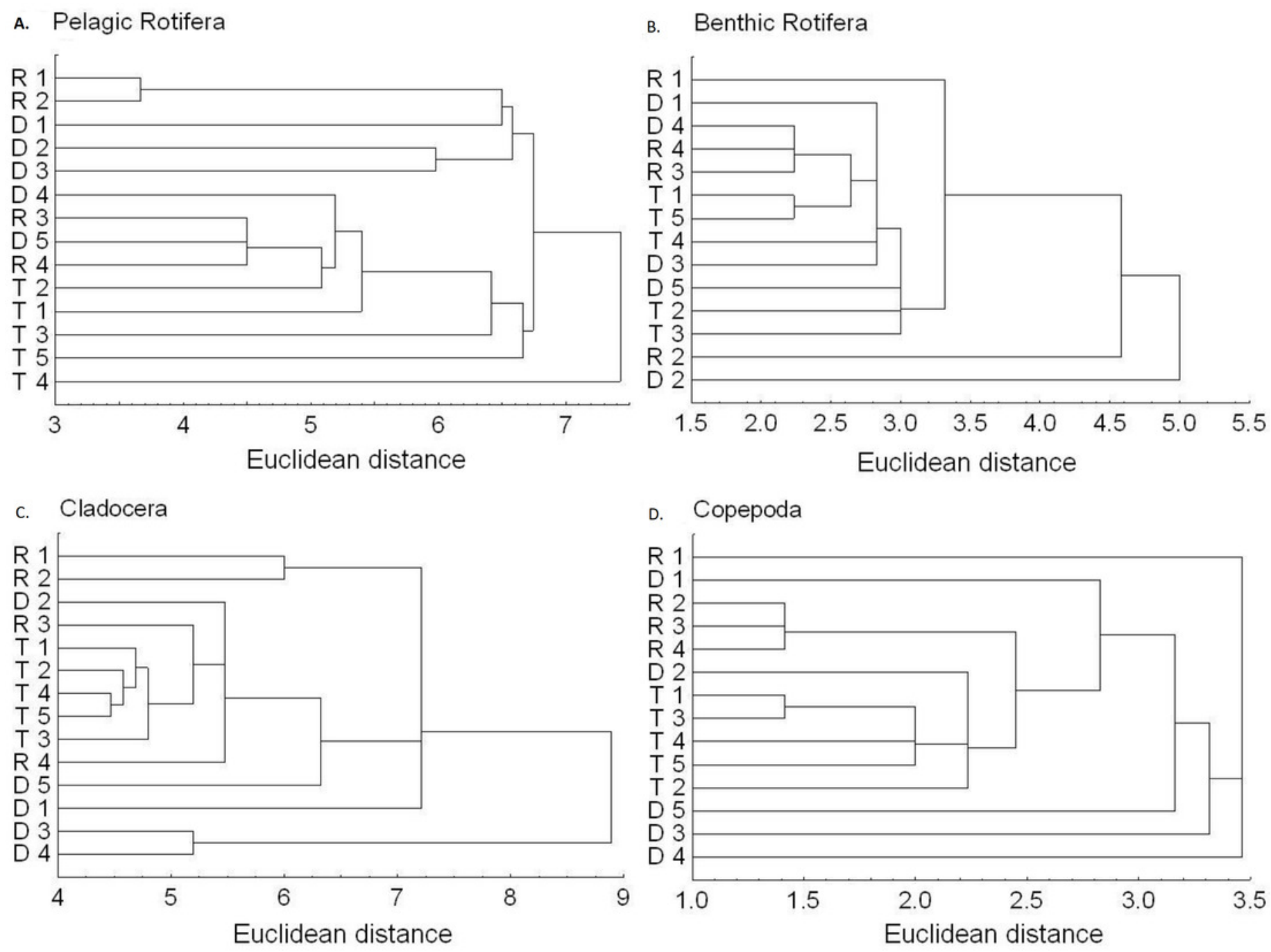


\section{Figure 5}

Spatial distribution of the zooplankton abundance in the Barycz river.

R 1-4: sites in the free-flowing waters of the Barycz, D 1-5: sites in the dams of Barycz, T 1-5: sites in the tributaries of the Barycz. 


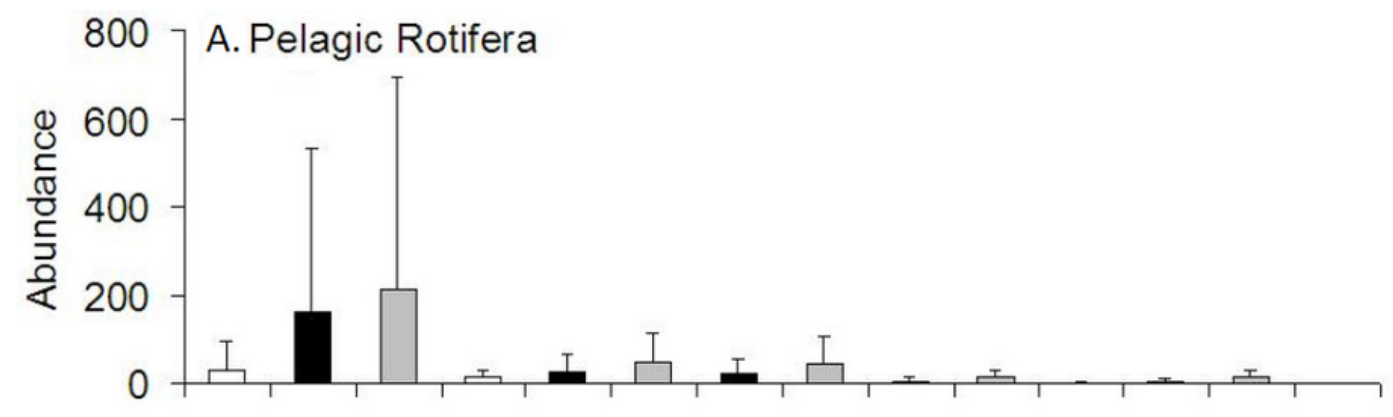

R 4 D 5 T 5 R 3 D 4 T 4 D 3 T 3 D 2 T 2 R 2 D 1 T 1 R 1

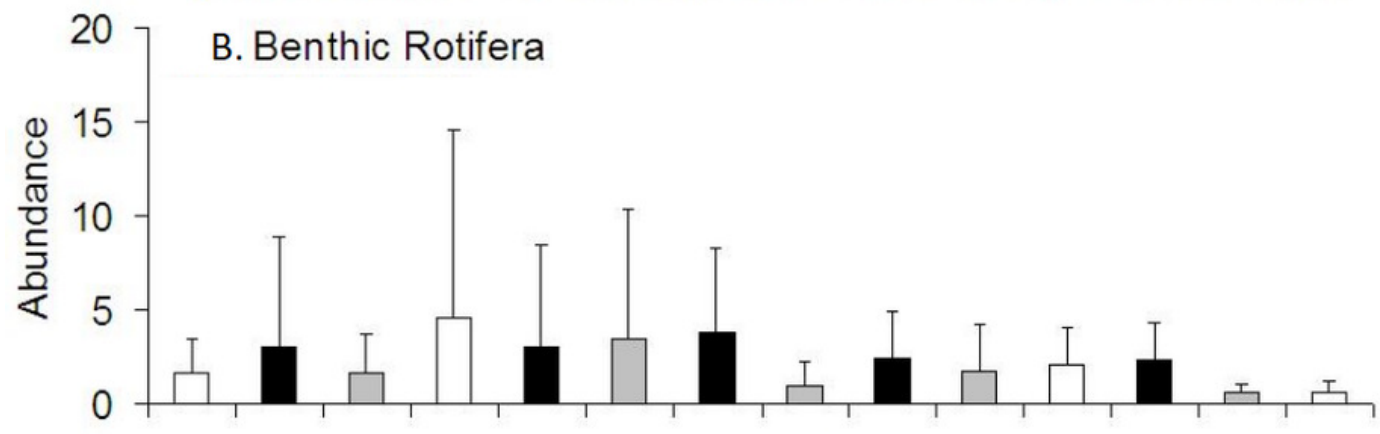

R 4 D 5 T 5 R 3 D 4 T 4 D 3 T 3 D 2 T 2 R 2 D 1 T 1 R 1

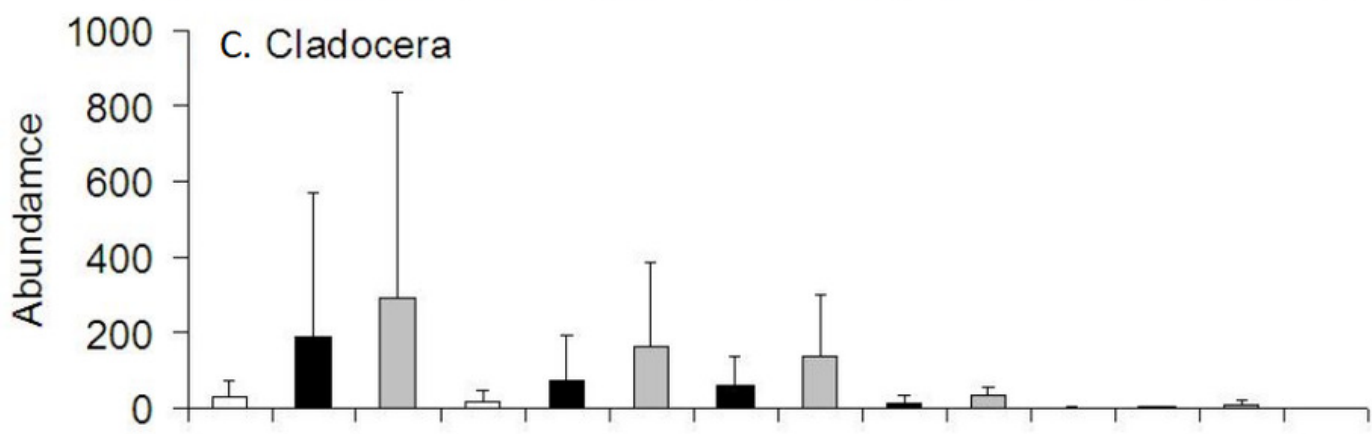

R 4 D 5 T 5 R 3 D 4 T 4 D 3 T 3 D 2 T 2 R 2 D 1 T 1 R 1

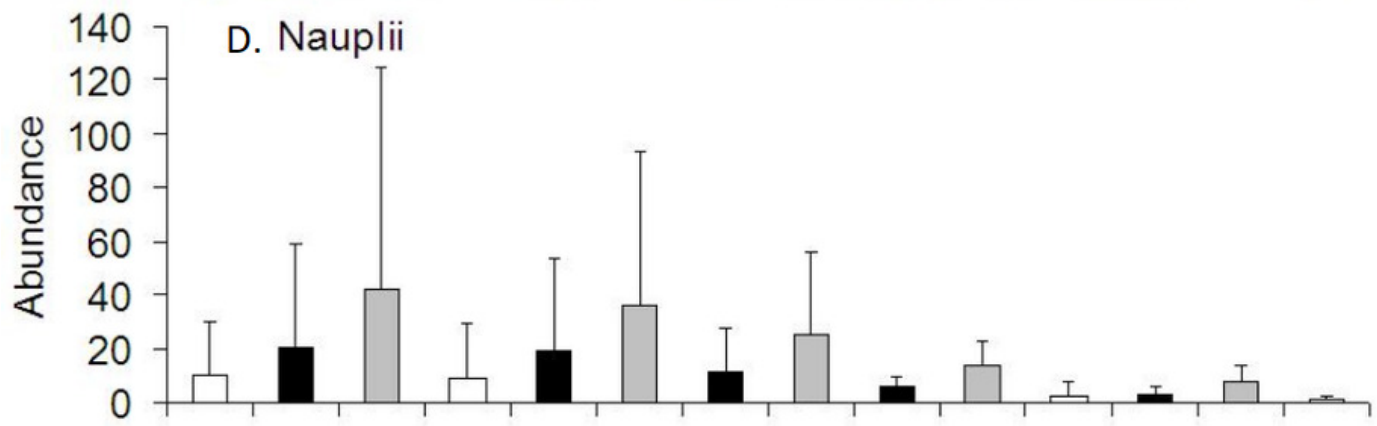

R 4 D 5 T 5 R 3 D 44 D 3 T 3 D 2 T 2 R 2 D 1 T 1 R 1

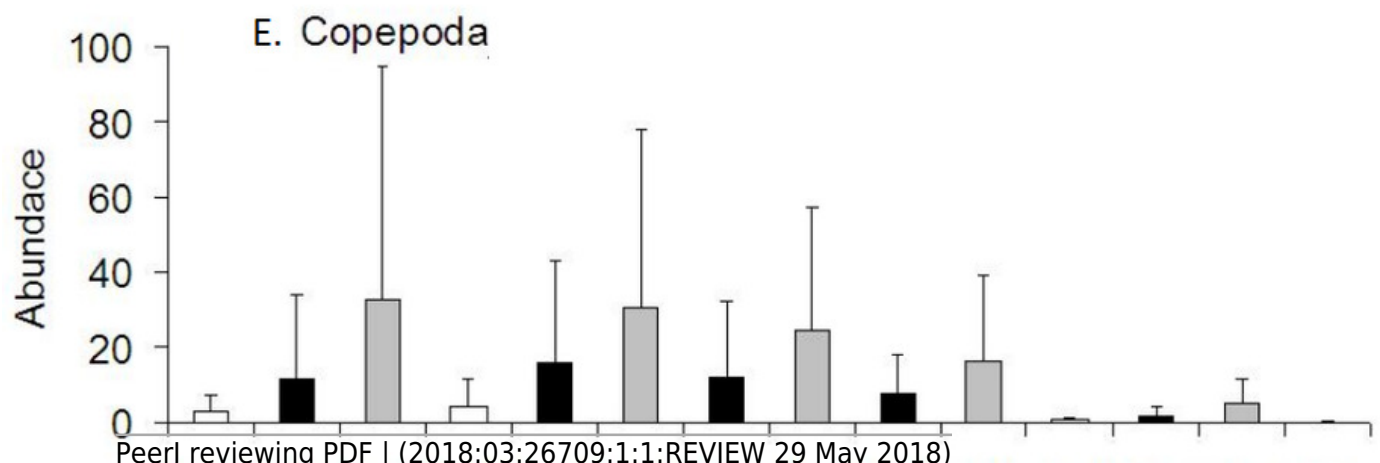




\section{Figure 6}

Dendrogram (cluster analysis) of the sites in the Barycz river.

R 1-4: sites in the free-flowing waters of the Barycz, D 1-5: sites in the dams of the Barycz, T 1-5: sites in the tributaries of the Barycz, based on the abundance of pelagic rotifers, benthic rotifers, cladocerans, Nauplii and copepods. 


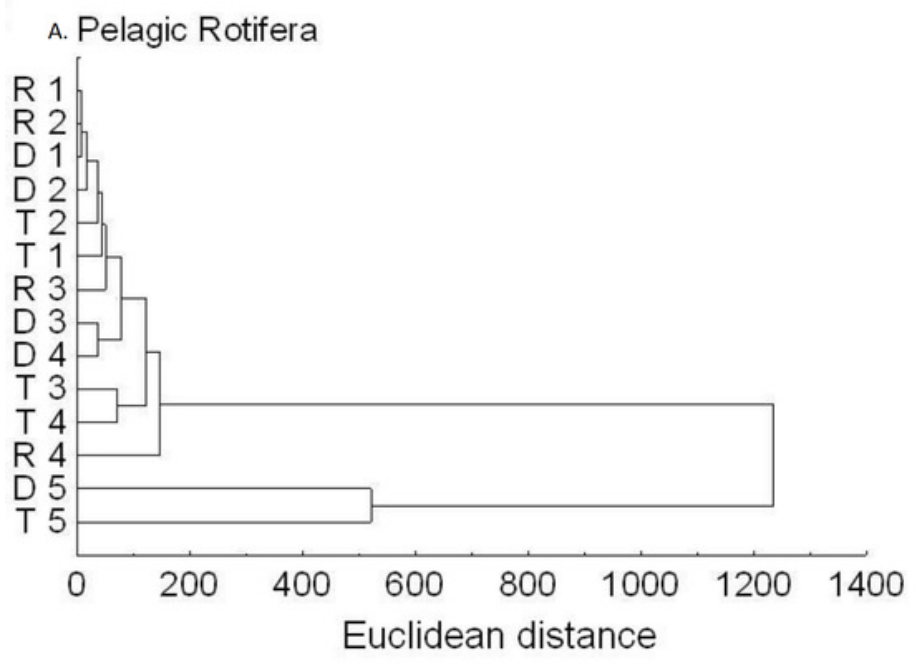

\author{
B. Benthic Rotifera
}
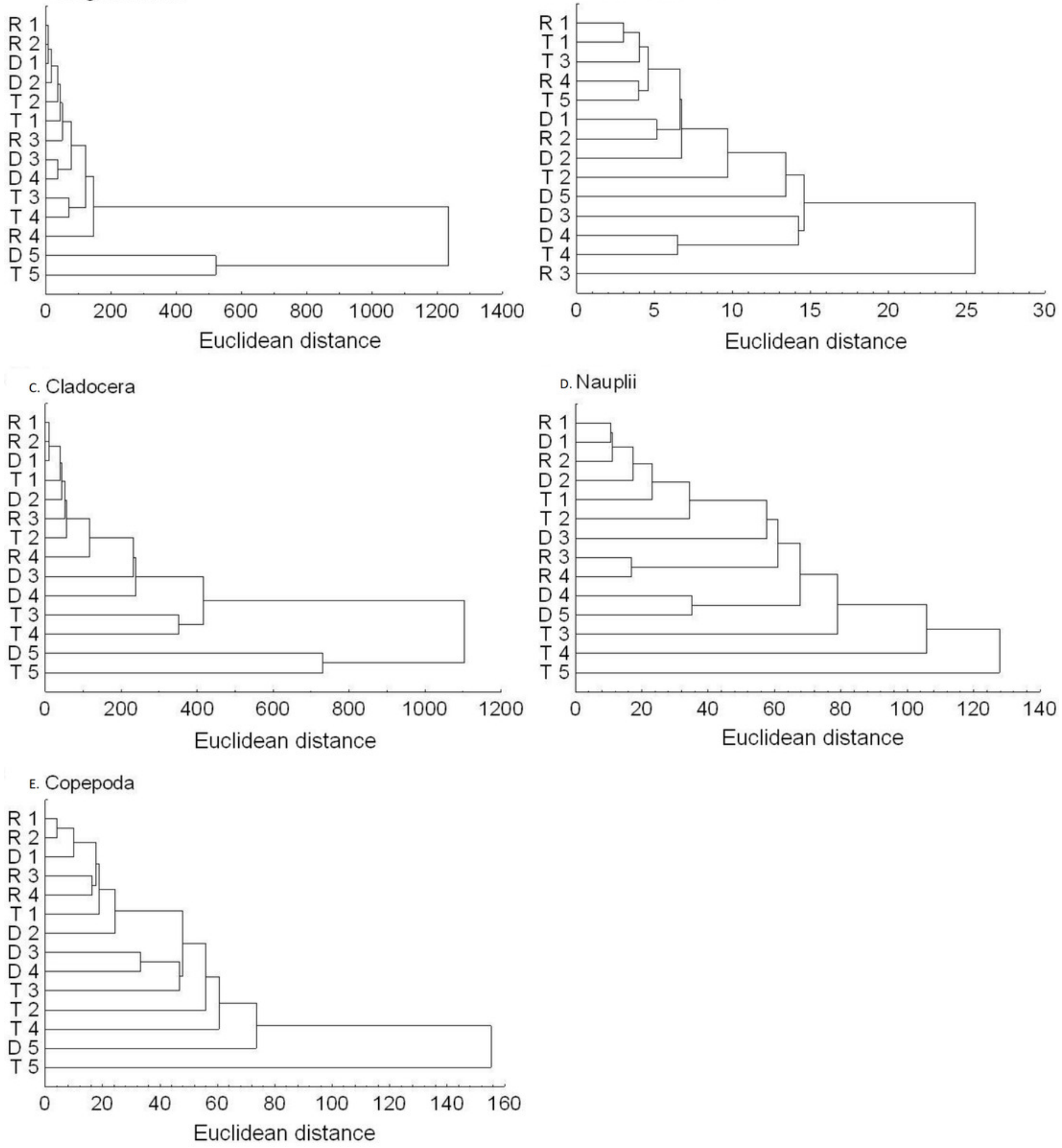
Figure 7

nMDS ordination for the abundance of all taxa at sites in the Barycz system.

The grouping in the nMDS ordination was based on the Bray-Curtis distances. Sites:

white-lotic sections of the river, grey-dammed sections of the river, black-tributaries (carp pond outlets). White triangle-R1, white square-R2, white circle-R3, white rhombus-R4, grey triangle-D1, grey square-D2, grey circle-D3, grey rhombus-D4, grey cross (X)-D5, black triangle-T1, black square-T2, black circle-T3, black rhombus-T4, black cross $(\mathrm{X})-\mathrm{T} 5$.

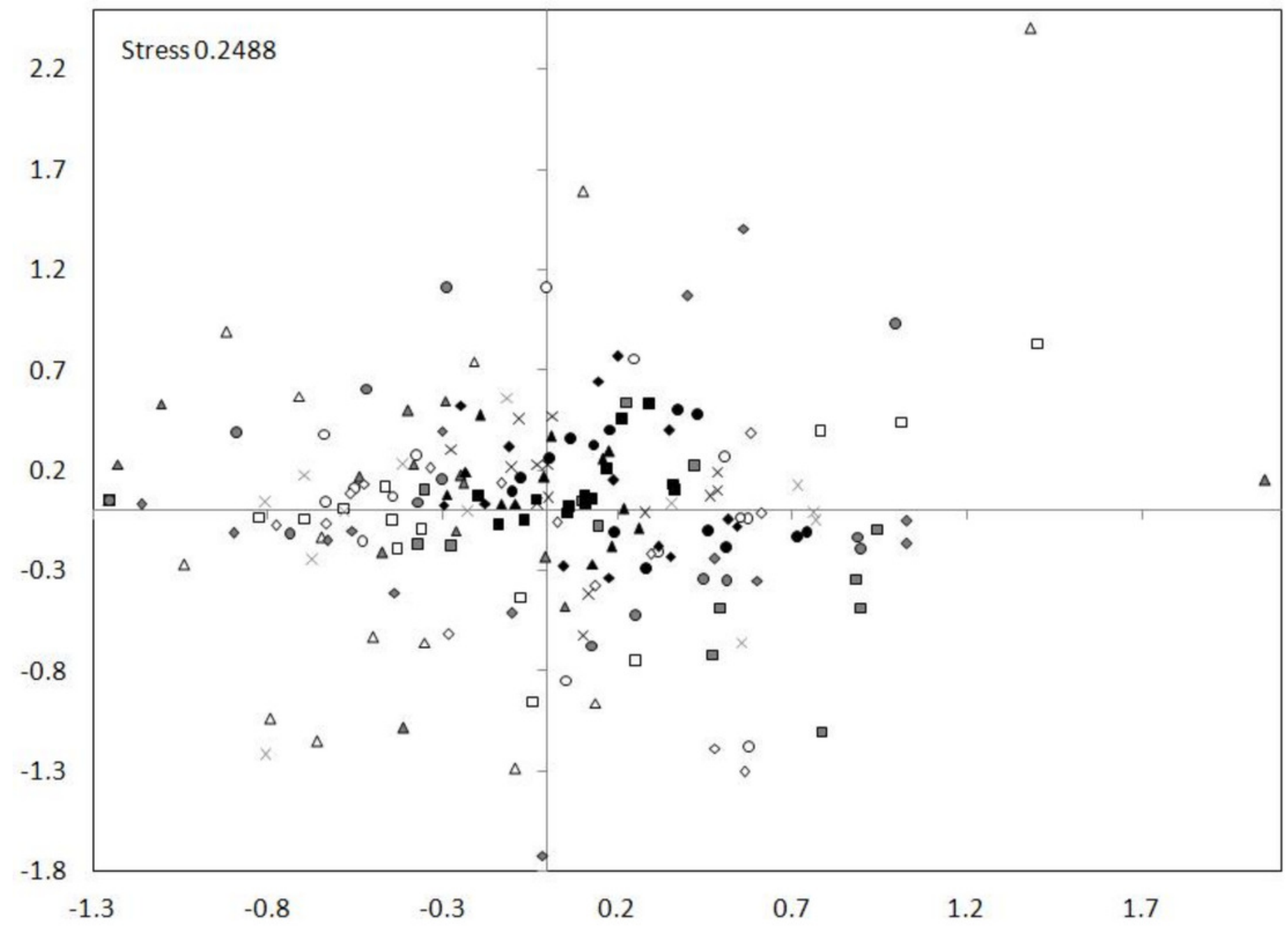


Figure 8

Percentage contribution of zooplankton groups in the mean total abundance of zooplankton at the sites examined in the Barycz river.

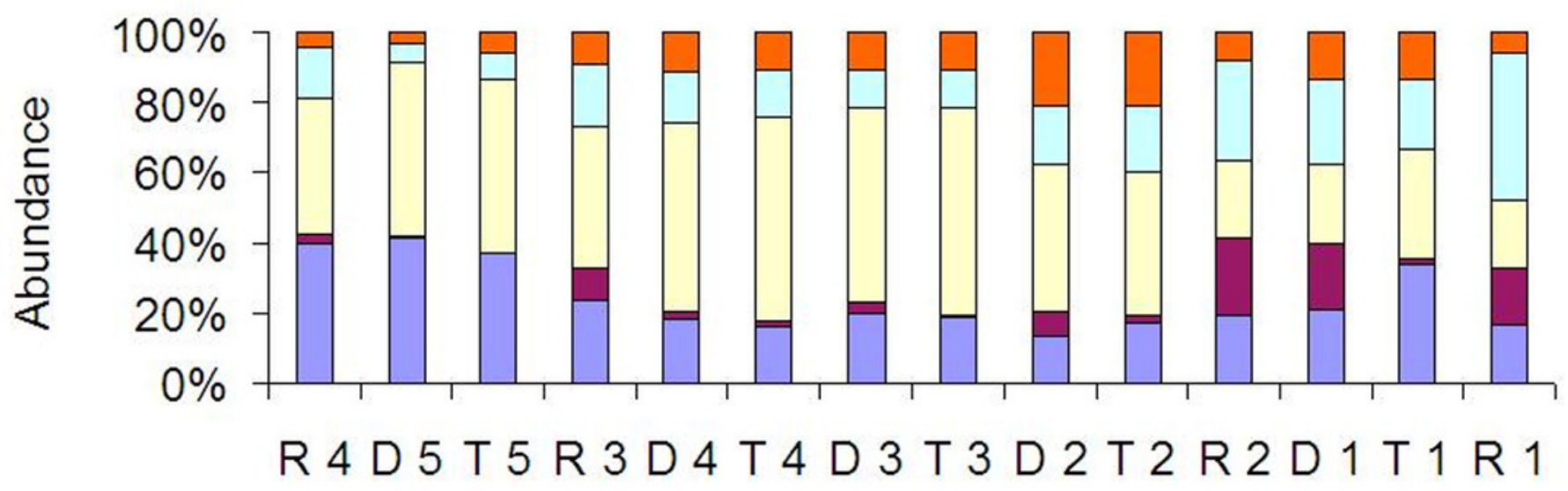

$\square$ Pelagic Rotifera

Benthic Rotifera

$\square$ Cladocera

$\square$ Nauplii Cyclopoida $\square$ Copepoda 


\section{Table $\mathbf{1}$ (on next page)}

Mean values \pm SD of chlorophyll a content, discharge and current velocity values and constant factors of the examined sites in the Barycz river.

Chl a-chlorophyll a content, velocity - current velocity, ND - number of dams above the site in the Barycz river, DCP - distance between the site in the Barycz river and the closest carp pond in the pond system, NCO - number of carp pond outlets (T) above the site in the Barycz river. Letters in column show significant differences between the sites. R 1-3: sites in the free-flowing waters of the Barycz river, D 1-5: sites in the dams of the Barycz river, T 1-5: sites in the tributaries of the Barycz river. 
1

\begin{tabular}{|c|c|c|c|c|c|c|}
\hline Site & Chl $a$ & Discharge & Velocity & ND & $\mathrm{DCP}$ & $\mathrm{NCO}$ \\
\hline & $\left(\mu \mathrm{g}^{-1}\right)$ & $\left(\mathrm{m}^{3} \mathrm{~s}^{-1}\right)$ & $\left(\mathrm{m} \mathrm{s}^{-1}\right)$ & & $(\mathrm{km})$ & \\
\hline R 1 & $\begin{array}{r}3.7 \\
\pm 2.3 \mathrm{a}\end{array}$ & $\begin{array}{c}0.27 \\
\pm 0.12 \mathrm{a}\end{array}$ & $\begin{array}{r}0.27 \\
\pm 0.06 \mathrm{a}\end{array}$ & 0 & - & - \\
\hline D 1 & $\begin{array}{c}8.3 \\
\pm 5.4 \mathrm{ab}\end{array}$ & $\begin{array}{c}0.34 \\
\pm 0.15 \mathrm{~b}\end{array}$ & $\begin{array}{c}0.08 \\
\pm 0.01 \mathrm{~b}\end{array}$ & 5 & 9.7 & 1 \\
\hline R 2 & $\begin{array}{c}10.2 \\
\pm 6.6 \mathrm{ab}\end{array}$ & $\begin{array}{c}2.00 \\
\pm 0.87 \mathrm{c}\end{array}$ & $\begin{array}{r}0.23 \\
\pm 0.05 \mathrm{a}\end{array}$ & 8 & 15 & 1 \\
\hline D 2 & $\begin{array}{r}13.5 \\
\pm 7.8 \mathrm{bc}\end{array}$ & $\begin{array}{c}2.16 \\
\pm 0.94 \mathrm{~cd}\end{array}$ & $\begin{array}{c}0.06 \\
\pm 0.02 \mathrm{~b}\end{array}$ & 11 & 0.3 & 2 \\
\hline D 3 & $\begin{array}{r}16.4 \\
\pm 9.2 \mathrm{bc}\end{array}$ & $\begin{array}{c}2.38 \\
\pm 1.04 \mathrm{cde}\end{array}$ & $\begin{array}{c}0.06 \\
\pm 0.02 \mathrm{~b}\end{array}$ & 13 & 0.1 & 3 \\
\hline D 4 & $\begin{array}{r}18.2 \\
\pm 8.9 \mathrm{bc}\end{array}$ & $\begin{array}{c}2.55 \\
\pm 1.11 \mathrm{cde}\end{array}$ & $\begin{array}{c}0.05 \\
\pm 0.02 \mathrm{~b}\end{array}$ & 15 & 0.1 & 4 \\
\hline R 3 & $\begin{array}{r}11.6 \\
\pm 6.9 \mathrm{bc}\end{array}$ & $\begin{array}{c}2.63 \\
\pm .1 .15 \mathrm{cde}\end{array}$ & $\begin{array}{r}0.16 \\
\pm 0.04 \mathrm{a}\end{array}$ & 16 & 7.3 & 4 \\
\hline D 5 & $\begin{array}{r}22.9 \\
\pm 10.3 \mathrm{c}\end{array}$ & $\begin{array}{c}4.27 \\
\pm 1.86 \mathrm{de}\end{array}$ & $\begin{array}{c}0.02 \\
\pm 0.02 \mathrm{~b}\end{array}$ & 23 & 6.9 & 5 \\
\hline R 4 & $\begin{array}{r}14.7 \\
\pm 6.6 \mathrm{bc}\end{array}$ & $\begin{array}{c}5.77 \\
\pm 2.51 \mathrm{e}\end{array}$ & $\begin{array}{r}0.39 \\
\pm 0.09 \mathrm{a}\end{array}$ & 31 & 36 & 5 \\
\hline
\end{tabular}

2

3

4 


\section{Table 2 (on next page)}

Taxonomical composition and frequency of total zooplankton at each site of the Barycz River and its tributaries.

R 1-4 sites on free-flowing stretch of the Barycz, D 1-5 sites on the dams, T 1-5 sites on the tributaries. Values in table are related to frequency.

Note: bold > 20\%; italic-bold 10-20\%; italic > 5\% of the mean total abundance of zooplankton at site in each stream, taxa that were lesser than $5 \%$ of the mean total abundance are not marked. 
1

\begin{tabular}{|c|c|c|c|c|c|c|c|c|c|c|c|c|c|c|}
\hline Taxa & R 1 & $\mathrm{~T} 1$ & D 1 & R 2 & T 2 & D 2 & T 3 & D 3 & $\mathrm{~T} 4$ & D 4 & R 3 & T 5 & D 5 & R 4 \\
\hline Ascomorpha saltans & & & & & & & 14 & 14 & 14 & 14 & & & & \\
\hline Asplanchna priodonta & & 14 & 14 & 14 & 43 & 43 & 14 & & 14 & & 43 & 71 & 43 & 29 \\
\hline Bdelloidea & 36 & 100 & 86 & 86 & 100 & 57 & 57 & 71 & 86 & 64 & 71 & 86 & 64 & 64 \\
\hline Brachionus angularis & 14 & 14 & 14 & & 14 & & & 21 & 14 & 14 & 36 & & 29 & 14 \\
\hline Brachionus calicyflorus & & 29 & & & 29 & 43 & 43 & 29 & 29 & 29 & 29 & 29 & 29 & 21 \\
\hline Brachionus diversicornis & & & & & & & 29 & 29 & 29 & 14 & 14 & 29 & 14 & \\
\hline Brachionus falcatus & & & & & & & 14 & & 14 & 29 & 14 & & & \\
\hline Brachionus leydigii & & & & & 14 & & & & & 14 & & & & \\
\hline Brachionus quadridentatus & 14 & 14 & 7 & 14 & & & 29 & 14 & 14 & 7 & & 14 & & \\
\hline Bracionus rubens & & 14 & 14 & & & & & & & & & 14 & 14 & 14 \\
\hline Brachionus urceoralis & & & 7 & & 14 & & & & 14 & & & 14 & 14 & 14 \\
\hline Cephalodella apocolea & 21 & & 21 & & & 14 & & 21 & & & 7 & 14 & 7 & \\
\hline Colurella adriatica & & 14 & 14 & & & & & 7 & & & 7 & & & \\
\hline Euchlanis dilatata & & 7 & & & & 21 & & 7 & & 7 & 14 & & 7 & 29 \\
\hline Filinia longiseta & & 14 & & 14 & 43 & 14 & 57 & 14 & 43 & 21 & & 43 & 14 & 14 \\
\hline Kellicottia longispina & & 7 & & & 14 & & 14 & & 57 & 14 & & 57 & 14 & 14 \\
\hline Keratella cochlearis & 21 & 100 & 71 & 14 & 100 & 43 & 86 & 29 & 100 & 29 & 71 & 100 & 57 & 71 \\
\hline Keratella quadrata & 14 & 71 & 36 & 43 & 71 & 43 & 100 & 29 & 86 & 29 & 50 & 86 & 57 & 64 \\
\hline Lecane clocterocerca & & & 14 & & & 14 & 29 & & & & & 14 & & \\
\hline Lepadella acuminata & 7 & & & 14 & & & & & 14 & & & & & \\
\hline Lepadella ovalis & & & & & & 14 & & & 29 & 14 & & & & \\
\hline Mytilina crassipes & & & & 14 & 14 & 14 & & & & & & & 14 & 14 \\
\hline Mytilina mucronata & 14 & 14 & 21 & 29 & 29 & 43 & & 43 & 29 & 36 & 36 & 29 & 21 & 57 \\
\hline Platyias quadricornis & 14 & & & 14 & & & 14 & 21 & 29 & 14 & & & & \\
\hline Polyarthra longiremis & & 14 & 14 & 14 & & & 14 & & & & & & & \\
\hline Polyarthra vulgaris & & & & 14 & & & 14 & 14 & 29 & 14 & 29 & 57 & 14 & 14 \\
\hline Scardinium longicaudatum & & & & & & 14 & & & & & & & & \\
\hline Synchaeta pectinata & & 14 & & & & 14 & 14 & 14 & & & & & & \\
\hline Synchaeta oblonga & & & & & & & & & & 14 & & & & \\
\hline Testudinella patina & 7 & & 7 & 7 & & & & 7 & & & 14 & & 14 & 7 \\
\hline Trichocerca capucina & 14 & & & & & & & & & & & & & \\
\hline Trichocerca similis & & & & 7 & & & & 14 & & 14 & 14 & & 14 & 14 \\
\hline Trichotria pocillum & & & & 14 & & & 14 & & & & & & & \\
\hline Acropeus harpae & 7 & & & & & & & 14 & 14 & 29 & 14 & & 14 & 14 \\
\hline
\end{tabular}




\begin{tabular}{|c|c|c|c|c|c|c|c|c|c|c|c|c|c|c|}
\hline Alona costata & 7 & & & & & & 14 & 14 & & 14 & & & & \\
\hline Alona guttata & & & & & & 29 & 14 & 14 & & 14 & & 14 & & \\
\hline Alona quadrangularis & & & & & & & & & & & & 14 & 14 & 21 \\
\hline Alona rectangula & & 14 & & 14 & 14 & 14 & & 29 & 14 & 29 & 14 & & 14 & 7 \\
\hline Alonella nana & & & & & & 14 & 14 & 29 & 14 & 29 & 14 & & 21 & 29 \\
\hline Eubosmina coregoni & & 14 & 14 & 14 & 43 & 14 & 14 & 14 & 14 & 14 & 14 & & 7 & \\
\hline Eubosmina longicornis & 7 & 21 & & 7 & & & 14 & 14 & 29 & 21 & 29 & 43 & 29 & 7 \\
\hline Eurycercus glacialis & & & & & & 14 & & & & 14 & & & & \\
\hline Bosmina gibbera & & & & & & & & & & & 14 & & & \\
\hline Bosmina longirostris & 14 & 71 & 50 & 43 & 86 & 71 & 86 & 43 & 100 & 71 & 57 & 86 & 64 & 86 \\
\hline Ceriodaphnia quadrangula & & 14 & & 14 & 43 & 29 & 43 & 43 & 43 & 29 & 43 & 43 & 14 & 7 \\
\hline Ceriodaphnia laticaudata & & & 14 & & & & & & & & & & 14 & \\
\hline Chydorus ovalis & & 29 & 29 & 14 & & 29 & 29 & 29 & & 29 & 29 & & 29 & 7 \\
\hline Chydorus sphaericus & 21 & 93 & 64 & 50 & 71 & 64 & 100 & 50 & 100 & 43 & 50 & 79 & 71 & 79 \\
\hline Daphnia cucullata & & & 14 & & 29 & 29 & 29 & 7 & 29 & 14 & & 29 & 14 & \\
\hline Daphnia longispina & & & & & 29 & 14 & & 14 & & 14 & & 57 & 29 & 7 \\
\hline Diaphanosoma brachyurum & & & & & & & 14 & 14 & & 14 & 14 & & & \\
\hline Disparolona rostrata & & & & & & & & & & & 14 & & & \\
\hline Graptoleberis testudinaria & & & & & & & & 14 & & 29 & & & & \\
\hline Peracantha truncata & & 14 & 14 & & & & & & & & & & & \\
\hline Pleuroxus trigonellus & & & & & & 14 & & & & & & & 14 & 14 \\
\hline Scapholeberis mucronata & & & & 14 & 29 & 14 & 14 & 14 & & & 14 & & 14 & 14 \\
\hline Simocephalus lusaticus & & & & & & & & 14 & 7 & & & & & \\
\hline Simocephalus serrulatus & & & & & & 14 & 14 & 14 & 14 & 14 & 10 & 14 & 14 & 14 \\
\hline Simocephalus vetulus & & & & & & & 14 & 14 & & 14 & & 14 & & \\
\hline Nauplii Cyclopoida & 79 & 100 & 79 & 79 & 100 & 93 & 100 & 79 & 93 & 79 & 86 & 100 & 93 & 100 \\
\hline Copepodit Cyclopoida & 21 & 86 & 43 & 71 & 100 & 79 & 100 & 86 & 100 & 64 & 71 & 100 & 57 & 57 \\
\hline Acanthocyclops robustus & 7 & 71 & 43 & 29 & 79 & 64 & 71 & 43 & 36 & 29 & 29 & 50 & 29 & 29 \\
\hline Eucyclops macruroides & 7 & & 14 & & 14 & 21 & & 36 & 21 & 29 & & 29 & 29 & 7 \\
\hline Eucyclops serrulatus & & 14 & & & 14 & 14 & 14 & & 7 & 7 & & 7 & & \\
\hline Eudiaptomus gracilis & & & & & & 7 & & & 7 & 21 & 14 & & 14 & 7 \\
\hline Megacyclops gigas & & & & 14 & & & & 7 & & 14 & & & 14 & \\
\hline Taxa number & 20 & 27 & 25 & 27 & 25 & 34 & 35 & 42 & 35 & 44 & 33 & 31 & 40 & 34 \\
\hline
\end{tabular}




\section{Table 3(on next page)}

All significant differences ( $P$-values) between the studied sites for the richness of the zooplankton groups (post-hoc multiple comparisons of mean ranks for all groups).

$* \mathrm{P}<0.05, * * \mathrm{P}<0.01, * * * \mathrm{P}<0.001$ 
1

\begin{tabular}{|c|c|c|c|c|c|c|c|c|c|c|}
\hline Group & Site & T 1 & T 2 & D 2 & T 3 & $\mathrm{~T} 4$ & R 3 & T 5 & D 5 & R 4 \\
\hline \multirow[t]{6}{*}{ Pelagic Rotifera } & R 1 & & $*$ & & $* * *$ & $* * *$ & & $* * *$ & & \\
\hline & D 1 & & & & $*$ & $*$ & & $* *$ & & \\
\hline & $\mathrm{R} 2$ & & & & $* *$ & $* *$ & & $* * *$ & & \\
\hline & D 2 & & & & & & & $* * *$ & & \\
\hline & D 3 & & & & & & & $*$ & & \\
\hline & D 4 & & & & & & & $*$ & & \\
\hline Cladocera & R 1 & $*$ & $* * *$ & * & $* * *$ & $* * *$ & * & $* * *$ & $*$ & * \\
\hline Copepoda & R 1 & & $*$ & & & & & & & \\
\hline
\end{tabular}

2

3

4

5

6

7

8

9

10

11

12

13

14

15

16

17

18

19

20

21

22 
Table 4(on next page)

All significant differences ( $P$-values) between the studied sites for the abundance of the zooplankton groups (post-hoc multiple comparisons of mean ranks for all groups).

$* \mathrm{P}<0.05, * * \mathrm{P}<0.01, * * * \mathrm{P}<0.001$ 
1

\begin{tabular}{lcccccccccc}
\hline Group & Site & T 1 & D 1 & R 2 & T 2 & D 2 & T 3 & T 4 & T 5 & R 4 \\
\hline Pelagic Rotifera & R 1 & $* *$ & & & $* * *$ & & $* * *$ & $* * *$ & $* * *$ & \\
\hline Cladocera & R 1 & $*$ & & & $* * *$ & $*$ & $* * *$ & $* * *$ & $* * *$ & \\
& T 2 & & $*$ & $*$ & & & & & & \\
\hline Nauplii & R 1 & & & & $* *$ & & $*$ & & $*$ \\
& T 2 & & & $*$ & & & & & & \\
\hline Copepoda & R 1 & $*$ & & & $* * *$ & $* *$ & $* * *$ & $* * *$ & $* * *$ & \\
& T 2 & & & $*$ & & & & & & $*$ \\
& T 3 & & $*$ & & & & & & $*$ \\
\hline
\end{tabular}

2

3

4

5

6

7

8

9

10

11

12

13

14

15

16

17

18

19

20

21

22 


\section{Table 5 (on next page)}

Spearman's significant correlations between richness and the values of environmental factors $(P<0.05)$.

Chlor_a - content of chlorophyll a, Velocity - current velocity, ND - number of dams above the site in the Barycz river, DCP - distance between the site in the Barycz river and the closest carp pond in the pond system, NCO - number of carp pond outlets above the site in the Barycz river, TPelRotR - richness of pelagic rotifers in the closest tributary above the site in the Barycz river, TBenRotR - richness of benthic rotifers in the closest tributary above the site in the Barycz river, TClaR - richness of cladocerans in the closest tributary above the site in the Barycz river, TCopR - richness of copepods in the closest tributary above the site in the Barycz river. 
1

\begin{tabular}{|c|c|c|c|c|}
\hline Variable & Pelagic Rotifera & Benthic Rotifera & Cladocera & Copepoda \\
\hline Chlor_a & 0.28 & 0.23 & 0.39 & 0.41 \\
\hline Velocity & & & & -0.35 \\
\hline ND & 0.32 & & 0.36 & \\
\hline DCP & & & & -0.22 \\
\hline NCO & 0.31 & & 0.35 & \\
\hline TPelRotR & 0.49 & 0.31 & 0.55 & 0.47 \\
\hline TBenRotR & & 0.31 & & \\
\hline TClaR & 0.60 & & 0.62 & 0.36 \\
\hline TCopR & 0.27 & 0.22 & 0.31 & 0.42 \\
\hline
\end{tabular}

2

3

4

5

6

7

8

9

10

11

12

13

14

15

16 


\section{Table 6(on next page)}

Spearman's significant correlations between abundance and the values of environmental factors $(P<0.05)$.

Chlor_a - content of chlorophyll a, Velocity - current velocity, ND - number of dams above the site in the Barycz river, DCP - distance between the site in the Barycz river and the closest carp pond in the pond system, NCO - number of carp pond outlets above the site in the Barycz river, TPelRotA - abundance of the pelagic rotifers in the closest tributary above the site in the Barycz river, TBenRotA - abundance of benthic rotifers in the closest tributary above the site in the Barycz river, TClaA - abundance of cladocerans in the closest tributary above the site in the Barycz river, TNaupCA - abundance of copepods Nauplii in the closest tributary above the site in the Barycz river, TCopA - abundance of copepods in the closest tributary above the site in the Barycz river. 


\begin{tabular}{|c|c|c|c|c|c|}
\hline & $\begin{array}{c}\text { Pelagic } \\
\text { Rotifera }\end{array}$ & $\begin{array}{c}\text { Benthic } \\
\text { Rotifera }\end{array}$ & Cladocera & $\begin{array}{c}\text { Nauplii } \\
\text { Cyclopoida }\end{array}$ & Copepoda \\
\hline Chlor_a & 0.32 & 0.30 & 0.50 & 0.45 & 0.40 \\
\hline Velocity & -0.20 & -0.18 & -0.29 & -0.29 & -0.32 \\
\hline ND & 0.33 & & 0.28 & & \\
\hline DCP & & & & & -0.26 \\
\hline NCO & 0.34 & & 0.28 & & \\
\hline TPelRotA & 0.81 & 0.57 & 0.72 & 0.66 & 0.68 \\
\hline TBenRotA & & 0.39 & & 0.29 & \\
\hline TClaA & 0.64 & 0.51 & 0.87 & 0.69 & 0.75 \\
\hline TNaupCA & 0.60 & 0.56 & 0.76 & 0.82 & 0.76 \\
\hline TCopA & 0.63 & 0.55 & 0.79 & 0.70 & 0.84 \\
\hline
\end{tabular}

1

2

3

4

5

6

7 